This PDF is a selection from an out-of-print volume from the National Bureau of Economic Research

Volume Title: NBER Macroeconomics Annual 1990, Volume 5

Volume Author/Editor: Olivier Jean Blanchard and Stanley Fischer, editors

Volume Publisher: MIT Press

Volume ISBN: 0-262-02312-1

Volume URL: http://www.nber.org/books/blan90-1

Conference Date: March 9-10, 1990

Publication Date: January 1990

Chapter Title: Wage and Employment Patterns in Long-Term Contracts When Labor is Quasi-Fixed

Chapter Author: Mark Bils

Chapter URL: http://www.nber.org/chapters/c10975

Chapter pages in book: (p. 187 - 236) 


\section{Wage and Employment Patterns in Long-Term Contracts When Labor Is Quasi-Fixed}

\section{Introduction}

Wage rigidities have played a central role in non-market-clearing explanations for sizable business cycles. ${ }^{1}$ The reason for this is presumably empirical. Many persons have their wage rates adjusted only once each year; and in collective agreements, which are particularly prevalent in industries with high-employment variability, it is common for wage rates to be renegotiated only every two or three years. Within these agreements indexation is very limited. ${ }^{2}$

Wage rigidity need not imply more variable employment-that depends on how employment is chosen given the wage behavior and on the nature of disturbances to the market. It has traditionally been assumed that firms choose employment unilaterally within the term of a labor contract, maximizing profits subject to the rigid wage. ${ }^{3}$ Behavior in actual contracts is often cited in support of this assumption. The twin assumptions of a rigid real wage and employment chosen unilaterally by

*For helpful comments, I thank Stanley Fischer, Lawrence Ball, my conference discussants Andrew Oswald and Gary Hansen, and participants at a lunchtime discussion at the Hoover Institution. I gratefully acknowledge financial support from the National Science Foundation, the University of Chicago Graduate School of Business, and the Hoover Institution.

1. This was true before the General Theory as well as since. See, for instance, Pigou (1927) and Haberler (1937).

2. For the United States in the postwar, indexation to the aggregate price level occurs very infrequently in contracts up to two years in length. About half of contracts over two years in length have been indexed to the CPI (see Bils 1989b). Indexation to factors other than the aggregate price level is extremely rare. Endogenous bonus payments and profit sharing have recently become less rare (see Kruse 1989).

3. For example, this is the assumption in Fischer (1977), Gray (1976), and Taylor (1979). 
firms can generate excessive movements (relative to flexible-wage solutions) in response to disturbances that shift labor demand. ${ }^{4}$ Furthermore, if the wage is predetermined in nominal terms, price-level surprises affect employment by altering real wage rates.

Barro (1977) criticizes this view of employment determination in the presence of rigid wages. In situations where the impact of wage rigidity would be important, he argues the parties should have strong incentive to find a way to avoid the easily identified losses from excessive variability. Hall (1980) suggests that long-term firm worker attachments may provide a setting where firms consider workers' preferences as well as the wage rate in choosing employment. The view that rigid-wage bargains are a veil behind which firms and workers trade labor in a flexiblewage manner is now pervasive in discussions of business cycles.

\subsection{THE WAGE PATTERN IN CONTRACTS}

I approach the issue of how employment is determined within long-term contracts by exploiting a predictable pattern that occurs in real wages during contracts. The pattern is a large real wage increase at the beginning of a new contract, with real wage growth then typically negative over the remainder of the contract. This pattern is presumably familiar to persons who have examined bargaining settlements. For a number of years the Bureau of Labor Statistics has published for major collective bargaining settlements separate rates of compensation growth for the first year of contracts versus the life of contracts.

I illustrate this front-loading of labor contracts with data for a large sample of the major collective bargaining agreements in manufacturing. These data were compiled at the Urban Institute from published reports

4. Hall (1988) notes the similar implications of a market-clearing model where workers have perfectly elastic labor supplies to a model with rigid real wages where firms choose employment, setting marginal revenue product equal to the wage. This similarity only pertains, however, to disturbances that shift labor demand. The rigid real-wage setting has the additional implication that disturbances that affect labor supply have their impact on employment and output muted. The rigid wage prevents workers from signaling through the market their willingness to provide additional labor at a given real wage. Although in terms of a single market such labor supply disturbances may be relatively unimportant, many of the aggregate disturbances that are often entertainedchanges in government spending, shifts in investment schedules or consumption functions-are usually modeled as affecting employment and output by creating a countermovement in real wages.

This suggests that an economy with rigid wages will fluctuate more dramatically in response to supply disturbances (e.g., an improved technology) and less to demand disturbances (e.g., an increase in government spending) than a comparable economy with flexible wages. A corollary is that supply disturbances may cyclically dominate even if the underlying disturbances are predominantly disturbances such as shifts in government spending or investment policies. 
on contracts contained primarily in the Bureau of Labor Statistics Current Wage Developments. They are described in detail in Vroman (1984) and Vroman (1986). (This data set is subsequently referred to as the Vroman data.) The data cover 3,071 contracts in manufacturing, with starting dates occurring within the years 1957 to $1983 .{ }^{5}$ The data contain information separately on contract wage changes that occur in the first year of a contract and on wage changes occurring during the balance of a contract.

Table 1 presents the growth of wages in the first year of these contracts compared to over their balance. Wage growth is expressed relative to the growth in straight-time wage rates in manufacturing as a whole over the corresponding months; it is expressed at an annual rate of growth. Attention is restricted to the 2,178 contracts $($ of 3,071$)$ with durations of at least two years. First, consider the bottom row of Table 1, which gives results for all 2,178 contracts. Not surprisingly, contract wage rates show no movement on average relative to straight-time wage rates in all of manufacturing. The contract wages typically grew by 1.11 percent relative to manufacturing in the first year. The contract data do not show whether this occurs from a one-time jump at the beginning of contracts or from faster growth throughout the first year. Evidence from industry data reported below, however, suggests it occurs at the front of the contract. The contract wages then lose this relative position by growing at a rate $0.64 \%$ per year less than total manufacturing over the remainder of the contract. Thus, contract wages in real terms grow $1.75 \%$ faster in the first year than over their balance.

The top panel of Table 1 breaks the contracts down by duration. For contracts of each category of length, wages grow considerably faster in the first year. The differential is larger, however, for longer contracts (those three-plus years in length).

One possible explanation for this sawtooth pattern in relative wages is simply that wage setters find it convenient to set a constant wage over the contract, updating it discreetly at contract points to reflect the growth of prices and real wages (as in Taylor, 1979). This view, however, can be rejected because contracts very rarely specify a constant wage over the contract. Of the 2,178 contracts represented in Table $1,92 \%$ specify a noncontingent wage increase at some point after the first year. Some of the remaining $8 \%$ experience an indexed wage increase; so only about 5 percent of the contracts exhibit no wage increases after the first year.

A related explanation is that contracters find it costly to index to inflation; lack of indexation requires discrete adjustment of wages at the front

5. Some contracts are reported that began prior to 1957 and after 1983; but the coverage for these earlier and later periods is much less representative of the complete bargaining pattern in manufacturing (see Bils 1989b). 
Table 1 ANNUAL RATE OF REAL WAGE GROWTH (RELATIVE TO STRAIGHT-TIME MANUFACTURING WAGES) IN LONG (2+ YEARS) UNION CONTRACTS*

\begin{tabular}{lccccc}
\hline & $\begin{array}{c}\text { \# } \\
\text { contracts }\end{array}$ & $\begin{array}{c}\text { Rate of } \\
\text { Growth } \\
\text { Duration }\end{array}$ & $\begin{array}{c}\text { Rate in } \\
\text { First Year }\end{array}$ & $\begin{array}{c}\text { Rate } \\
\text { During } \\
\text { Balance }\end{array}$ & $\begin{array}{c}\text { First Year } \\
\text { Minus } \\
\text { Balance }\end{array}$ \\
\hline By Length & & & & & \\
24 Mos. & 669 & 0.14 & 0.80 & -0.53 & 1.33 \\
& & $(0.87)$ & $(.124)$ & $(.101)$ & $(.137)$ \\
25-35 Mos. & 278 & 0.18 & 0.81 & -0.21 & 1.02 \\
& & $(.135)$ & $(.192)$ & $(.157)$ & $(.212)$ \\
36 Mos. & 1108 & -0.04 & 1.36 & -0.73 & 2.10 \\
& & $(.068)$ & $(.096)$ & $(.078)$ & $(.106)$ \\
> 36 Mos. & 123 & -0.56 & 1.28 & -1.30 & 2.59 \\
& & $(.203)$ & $(.288)$ & $(.235)$ & $(.319)$ \\
By Indexation & & & & & \\
Not Indexed & 1349 & -0.35 & 0.87 & -1.13 & 2.00 \\
& & $(.060)$ & $(.087)$ & $(.069)$ & $(.097)$ \\
Indexed & 829 & 0.61 & 1.51 & 0.17 & 1.34 \\
& & $(.077)$ & $(.111)$ & $(.088)$ & $(.123)$ \\
For All & 2178 & 0.02 & 1.11 & -0.64 & 1.75 \\
>= 24 & & $(.048)$ & $(.069)$ & $(.056)$ & $(.076)$ \\
\hline
\end{tabular}

*Standard errors are in parentheses. Contracts are settled in years 1957 through 1983.

of each contract to respond to unexpected inflation (or unexpected real wage growth) occurring during the term of the preceding contract. The obvious problem for this explanation is that it requires contractors to consistently and sizably underpredict nominal wage growth on average for the entire 27 years being considered. In fact, the differential in wage growth for the first year of contracts is statistically and quantitatively positive for each and every year of the 1960s and 1970s. ${ }^{6}$ The second panel of Table 1 presents results separately for contracts indexed to inflation and those that are not. Although the first-year wage growth differential is larger for nonindexed contracts, it is very large and statistically significant for indexed contracts as well. ${ }^{7}$

6. Over the 1960s and 1970s, inflation rates did on average exceed expected inflation as given by the Livingston Index of Inflation forecasts (Caskey 1985, page 769). The wedge between actual and expected, however, was largely confined to the years 1969-70,197374, and 1978-79.

7. Note the striking feature that indexed contracts have much more rapid wage growth than nonindexed-gaining $3 \%$ on nonindexed over a three-year contract. This feature is discussed in detail in Bils (1989b). I know of no compelling explanation for why contracts with high-expected wage growth should be so much more inclined to be indexed. 
I find the most plausible interpretation to be that bargainers construct wage paths with an objective of concentrating wage increases at the beginning of contracts; this results in sizable and predictable real wage variability over the contract.

\subsection{OVERVIEW}

The paper is composed of five sections, the first of which is this Introduction. Section 2 examines patterns in employment during contracts. The obvious question is whether employment predictably increases over a contract as real wages predictably decline. This is the implication of simply applying the framework of firms unilaterally setting employment subject to the wage.

The contract data do not contain time series for employment. To examine employment behavior I consider two alternative data sources. First, in industries where bargaining occurs in distinct patterns across time, I match spikes in bargaining activity to industry-level employment and turnover data. Second, in some cases collective bargaining occurs with a significant fraction of a company's work force. I examine annual employment series derived from company annual reports for 40 such companies represented in the Vroman contract data.

The wage patterns depicted in Table 1 show up clearly in three-digitlevel industry wage rates as well-wage rates increase markedly in an industry immediately after a number of workers in that industry receive new contracts. As a rule, industry employment shows no corresponding decrease when wages are predictably increasing at the beginning of a contract. In fact on average, there is higher employment growth at the beginning of contracts. This average pattern, however, hides considerable differences across industries: some industries (particularly motor vehicles) have higher employment growth during the early part of a contract, whereas others have slower growth at the beginning. Employment for the 40-company exhibits behavior consistent with the industry results: that is, employment declines over the course of contracts as wage rates decline.

To properly draw conclusions from these predictable wage and employment patterns requires a theoretical framework that predicts the decline in wage rates during contracts. Section 3 presents a model to explain the structure of long-term labor contract, in particular wageemployment patterns within contracts. The starting point is the presumption that the demand by firms for labor is dynamic. The notion of labor as a quasi-fixed factor was pioneered by Clark (1923) and Oi (1962).

In a bargaining setting dynamic labor demand provides an important rationale for long-term bargains. The setting I consider is a monopoly 
union setting wages for a firm or group of firms. With labor quasi-fixed, labor demand this period depends negatively on anticipated future wage rates. In setting its wage today, a union would like to convince firms that in future periods it will reduce its wage demands. But this is not credible; firms know that when the future arrives the union will demand whatever wage maximizes its objective. By offering firms a long-term agreement, however, it is possible for the union to successfully precommit to lower wages for the remainder of the agreement. Such commitment is desirable to the union. It will also typically be preferable for the firms. The long-term agreements will have lower wages on average than a series of shorter agreements.

The model has very sharp predictions for the dynamics of wages and employment. It predicts strongly declining wage rates over the life of a contract. The model's predictions for employment behavior over contracts depend crucially on the nature of industry bargaining. If the union bargains with a large number of firms as a group, then no firm has incentive to influence subsequent bargains by laying off workers. Therefore, the decline in wages over contracts implies an increase in employment. If an industry has few firms or bargains independently, then firms have incentive to reduce employment toward the end of a contract to achieve a lower wage in the subsequent agreement. This suggests that industries with few firms or less of a bargaining pattern should not exhibit significant increases in employment during contracts despite predictably declining wage rates.

Section 4 tests specific implications derived from this model of longterm labor contracts. I test whether wage declines during contracts are more pronounced in industries where labor is better described as quasifixed. (In turn, quasi fixity is proxied by average industry wages or turnover rates.) I examine whether industries where union settlements are industrywide are more likely to display growing employment in response to wage declines over contracts. Examples are industries with a strong bargaining pattern across firms or where the contract applies to many firms as a group. From company data I test whether dominant firms in such industries are more likely to have declining employment over a contract. The model suggests such firms will have a stronger incentive to reduce employment over a contract because they have greater influence on the industrywide future wage settlements. (For example, I examine whether employment is more likely to decline during contracts at General Motors than at its smaller competitors.) The evidence in Section 4 is not supportive of the explanations for wageemployment patterns derived from dynamic labor demand.

The final section (Section 5) briefly summarizes and attempts conclu- 
sions. I interpret the behavior of employment as inconsistent with the traditional view of employment determined largely by firms in the short run, even allowing dynamic labor demand. The behavior of employment is reasonably consistent with the view of wages as nonallocative in the short run; but this leaves unexplained the predictably large patterns in wages. I conjecture a possible alternative to these extremes, in which bargainers are able to tie themselves more closely to the contract curve (jointly efficient bargains) at earlier dates into a contract.

\section{Patterns in Employment and Labor Turnover During Contracts}

The introduction presented the economically and statistically large impact of bargaining dates on wage behavior. This section attempts to display the corresponding within contract pattern in employment.

The contract data do not contain time series for employment. They do contain the number of workers represented at the date of the contract. These numbers are best interpreted as benchmarks for the size of the bargain negotiated. Union members who are currently unemployed are often included in these figures. Furthermore, studying within-contract employment patterns by definition requires more frequent observations than the bargaining dates. I consider two alternative data sources for employment data. First, I examine industry data at the three-digit level for a group of industries for whom I can date the periods with new contracts for a significant fraction of the industry's workers. I also relate the pattern in employment to patterns in industrywide quits, layoffs, and new hires. Second, I examine annual-report employment numbers for a set of companies who have a significant fraction of their workers represented by collective agreements in the Vroman data.

\subsection{CONTRACT EFFECTS ON INDUSTRY EMPLOYMENT}

In this section I relate wage and employment behavior from industry data to contracting dates by exploiting concentrations of contracting activity in individual industries. I will implicitly treat contract dates as an instrument for examining the relation of wages and employment. This ignores the possibility that contract dates are endogenous with the important exception of seasonal patterns. I believe this is a valid exercise. Almost all the contracts have an explicit end date and a very large fraction end at or near the scheduled date. Only $7 \%$ of the contracts end prematurely (Bils, 1989b). Below I isolate these $7 \%$ to test that their endogenous endings do not significantly affect the estimates.

I match contracting dates to industry employment data as follows. The 
Vroman contract data represent 252 bargaining situations and involve workers in 85 different three-digit manufacturing industries. ${ }^{8}$ For each of these 85 industries I created a time series for years 1958 to 1984 for the number of workers represented by agreements in the Vroman contract data. This equals the number of contracts in effect at a point in time, weighted by the number of workers represented. (I choose 1958 as the beginning year because industry employment data begin in 1958 for a majority of industries.) I further broke this time series into four component time series: the number of workers in the first quarter of a contract, the number of workers in the remainder of the first year of a contract, the number of workers in the second year of a contract, and the number of persons in the third or later year of a contract. The time series are quarterly, calculated for each of the months of January, April, July, and October for each year from 1958 to 1984 . One of these months is in the first quarter of a new contract if settlement of a contract occurred in one of the preceding three months. (For instance, January 1980 is the first observation of a new contract if settlement occurred in either October, November, or December of 1979.)

A key factor in matching contracting to industry employment is the fraction of workers involved in contracts in the data. Define industry coverage by the following average:

$$
S=\frac{1}{T} \sum_{t=1}^{T} \frac{\text { Contract Employment }}{\text { Industry Employment }_{t}}
$$

$S$ implicitly has an industry-specific subscript. $t$ runs from 1958 to $1984 .^{9}$ Industry employment is production-worker employment from the Bureau of Labor Statistics Establishment Survey. $S$ is quite small for a number of the 85 industries represented in the contract data set. I restrict subsequent matching solely to those industries for whom coverage $(S)$ is greater than $10 \%$. This reduces the number of industries to 40 . These industries are listed in Table 2 together with their coverage rate $(S)$. I also

8. A bargaining situation is a continued negotiating match. In a majority of cases this is a single union and single firm. In about one-fourth of cases it is a single union and multiple firms who receive a common agreement. In a very small subset of cases it involves multiple unions bargaining together. One of the 85 industries I consider is actually the two-digit industry number 36 , electrical products. The large companies in this case (General Electrical, Westinghouse) are so diversified that it is impossible to fit them into a three-digit industry. The two three-digit industries, SIC 261 and SIC 262, are combined in the BLS data so I combine their contracting dates.

9. For a few industries employment is only available for 1972 and after. 
Table 2 EMPLOYMENT COVERED IN CONTRACT DATA AS FRACTION OF INDUSTRY PRODUCTION WORKERS

\begin{tabular}{lccr}
\hline $\begin{array}{l}\text { Industry } \\
\text { SIC\# }\end{array}$ & $\begin{array}{c}\text { Data } \\
\text { Coverage }\end{array}$ & $\begin{array}{c}\text { Industry } \\
\text { SIC \# }\end{array}$ & $\begin{array}{c}\text { Data } \\
\text { Coverage }\end{array}$ \\
\hline 202 & .140 & $321^{*}$ & .754 \\
$203^{*}$ & .349 & $322^{*}$ & .331 \\
206 & .166 & $324^{*}$ & .331 \\
$211^{*}$ & .416 & 326 & .142 \\
221 & .134 & 331 & .225 \\
226 & .198 & $333^{*}$ & 1.235 \\
$231^{*}$ & 1.220 & $341^{*}$ & .488 \\
$232^{*}$ & .341 & 351 & .194 \\
$233^{*}$ & .454 & $352^{*}$ & .989 \\
234 & .130 & 360 & .101 \\
236 & .152 & 362 & .225 \\
242 & .145 & 363 & .207 \\
$261 / 262$ & .155 & $365^{*}$ & .388 \\
$263^{*}$ & .318 & 366 & .162 \\
281 & .231 & 369 & .106 \\
282 & .158 & $371^{*}$ & 1.074 \\
291 & .170 & $372^{*}$ & .379 \\
$301^{*}$ & .859 & $373^{*}$ & .345 \\
314 & .132 & $374^{*}$ & .416 \\
$317^{*}$ & .381 & 387 & .171 \\
\hline
\end{tabular}

*Industries with coverage greater than $25 \%$, included in more restrictive sample.

present results below for a more restrictive sample of 19 industries for whom the coverage rate is greater than $25 \%$. In three of the highly unionized industries, men's apparel (SIC 231), aluminum and other metals (SIC 333), and motor vehicles (SIC 371), the coverage is greater than one-presumably because the contract number of workers reflects some unemployed and some nonproduction workers. I set $S$ equal to one for these three industries.

For the remaining 40 industries I examine the impact of contract dates by regressing rates of growth in industry wages and employment on the fraction of workers at each point in a contract. The estimated equations are:

$$
\begin{aligned}
\begin{aligned}
\text { Wage } \\
\text { Growth }
\end{aligned}=\text { Const }+a_{1} s \frac{(1 \text { st Quart Emp })}{\text { Contract Emp }} & +a_{2} s \frac{(1 \text { st Year Emp })}{\text { Contract Emp }} \\
& +a_{3} s \frac{(3 r d+\text { Year Emp })}{\text { Contract Emp }}
\end{aligned}
$$




$$
\begin{aligned}
\underset{\text { Growth }}{\text { Emp }}=\text { Const }+b_{1} s \frac{(1 \text { st Quart Emp })}{\text { Contract Emp }} & +b_{2} s \frac{(1 \text { st Year Emp })}{\text { Contract Emp }} \\
& +b_{3} s \frac{(\text { (3rd }+ \text { Year Emp })}{\text { Contract Emp }} .
\end{aligned}
$$

Wages and employment data are, respectively, average hourly earnings and production worker employment from the BLS Establishment Survey. Wages are measured relative to straight-time wages for all manufacturing for the same months. Similarly, employment is relative to productionworker employment for all manufacturing. First-year employment means excluding workers in the first quarter of contracts. Workers in the second year of contracts are the reference group. $a^{\prime}$ s and $b^{\prime}$ s are parameters. Note that observations are weighted by the coverage rate. This assumes that having all contracts expire in an industry where only $10 \%$ of the industry is covered by major agreements will have one-tenth the impact of all contracts expiring in an industry that is entirely covered by agreements. ${ }^{10}$ If agreements in an industry were perfectly uniformly distributed over time the right-hand-side variables would all be constants. This is not the case. A number of industries have distinct bargaining patterns; in some cases a large majority of workers are all represented by new agreements within the span of a few weeks (see Bils, 1989a).

The 40 industries provide 4,112 observations on rates of growth. (This is 1958:2 to 1984:4 for all industries, except SICs 203, 281, and 352 are for 1972:2 to 1984:4 because BLS data are only available from 1972.) It is necessary to eliminate some observations due to strikes. Strikes have the impact of reducing employment at the end of one contract as workers go on strike, then increasing employment at the beginning of the subsequent contract as workers have returned. I eliminated all quarterly observations that occur during a strike, as well as the subsequent quarterly observation. I view the entire industry observation as strike polluted no matter how few workers are on strike. Data on strike occurrences are contained in the Vroman contract data. Fortunately many strikes are sufficiently short that they do not overlap with the measurements of employment at quarterly intervals. ${ }^{11}$ One hundred and sixteen observations were lost to strikes, leaving a total of 3,996 quarterly observations.

10. This assumption will fail, for instance, where a number of firms in an industry set wages outside of major agreements but in a manner to mimic the major agreements.

11. The Establishment Survey measures monthly employment by the number of employees who were employed during the pay period covering the fifteenth of that month. I designated any month for which a strike was in progress on the fifteenth a strikepolluted month. Thus, I erred in the direction of eliminating periods not affected by strikes in order to be certain that all periods with strikes were captured. 
The regressions for equations (2A) and (2B) additionally incorporate industry-specific constants and seasonal dummies. I also consider industry-specific seasonal dummies.

Results for wage growth appear in Table 3. The first two rows use all 40 industries for which contract coverage is greater than $10 \%$. I will focus primarily on the second row, which allows for industry-specific seasonals. Wage growth is much faster in the first quarter of a contract. Wages grow $1.38 \%$ faster in the first quarter relative to the second year of contracts. Wage growth during the remainder of the first contract year and past the second year of the contract is not significantly different than growth in the second year. These estimates are extremely consistent with the finding from the contract-data wages in Table 1 that wages grow $1.75 \%$ faster in the first contract year. The estimates in row 2 of Table 3 imply $1.83 \%$ faster wage growth in the first contract year than in the second. (This equals the first-quarter effect, $1.38 \%$, added to three quarters of $0.15 \%$ faster wage growth in quarters two through four of the first contract year.) The estimates here, however, provide the additional information that most of the first-year effect occurs at the very front of the contract.

I also estimated industry-specific effects of contract dates. The F-tests in Table 3 are against a null hypothesis that the contract date effect equals zero for all industries. The F-tests for the first and third year

\section{Table 3 QUARTERLY RATES OF WAGE GROWTH BY POINT IN CONTRACT, INDUSTRY DATA*}

\begin{tabular}{|c|c|c|c|c|c|c|}
\hline & $\begin{array}{l}\text { Common } \\
\text { 1st-Quart } \\
\text { Effect }\end{array}$ & $\begin{array}{l}\text { Common } \\
\text { 1st-Year } \\
\text { Effect }\end{array}$ & $\begin{array}{c}\text { Common } \\
\text { 3rd-Year } \\
\text { Effect }\end{array}$ & $\begin{array}{l}\text { F-test } \\
\text { for } \\
\text { 1st Quart }\end{array}$ & $\begin{array}{l}\text { F-test } \\
\text { for } \\
\text { 1st Year }\end{array}$ & $\begin{array}{c}\text { F-test } \\
\text { for } \\
\text { 3rd Year }\end{array}$ \\
\hline \multicolumn{7}{|l|}{ Sample E Specification } \\
\hline $\begin{array}{l}40 \text { Industries- } \\
\text { Common Seasonals }\end{array}$ & $\begin{array}{c}2.17 \\
(7.76)\end{array}$ & $\begin{array}{c}-0.10 \\
(-0.55)\end{array}$ & $\begin{array}{c}-0.25 \\
(-1.41)\end{array}$ & $4.75^{+}$ & 0.80 & 0.64 \\
\hline $\begin{array}{l}40 \text { Industries-_- } \\
\text { Industry-Specific } \\
\text { Seasonals }\end{array}$ & $\begin{array}{c}1.38 \\
(5.51)\end{array}$ & $\begin{array}{c}0.15 \\
(1.00)\end{array}$ & $\begin{array}{l}-0.21 \\
(-1.38)\end{array}$ & $3.34^{+}$ & 0.90 & 0.70 \\
\hline $\begin{array}{l}19 \text { Industries- } \\
\text { Common Seasonals }\end{array}$ & $\begin{array}{c}1.73 \\
(5.82)\end{array}$ & $\begin{array}{c}-0.02 \\
(-0.13)\end{array}$ & $\begin{array}{c}-0.31 \\
(-1.72)\end{array}$ & $4.24^{+}$ & 0.61 & 0.78 \\
\hline $\begin{array}{l}19 \text { Industries-_- } \\
\text { Industry-Specific } \\
\text { Seasonals }\end{array}$ & $\begin{array}{c}1.19 \\
(4.27)\end{array}$ & $\begin{array}{c}0.14 \\
(0.88)\end{array}$ & $\begin{array}{l}-0.26 \\
(-1.63)\end{array}$ & $2.47^{\dagger}$ & 1.01 & 0.89 \\
\hline
\end{tabular}

*The 40-industry sample has 3,936 observations; the 19-industry sample has 1,830. T-statistics are in parentheses.

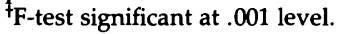


effects accept the null hypothesis that for all industries wage growth is constant after the first quarter of a contract. The pattern of first-quarter effects across industries is discussed shortly below.

Constraining industries to have common seasonal effects (see row 1) raises the estimated first-quarter effect to $2.17 \%$. But the data strongly reject the restriction of common seasonal effects.

The second panel of Table 3 reduces the sample to the 19 industries for which the contract data cover $25 \%$ of industry employment. The results are very similar to that obtained with the broader 40 industry sample.

Results for employment growth appear in Table 4. I again focus most discussion on the results when industry-specific seasonals are allowed. For the sample as a whole, employment growth is definitely not slower at the beginning of contracts when wages are sharply increasing. Employment actually grows 3\% faster in the first year than in the second (from a quarterly rate differential of approximately three-quarters of a percent). The estimate for the first quarter by itself is statistically insignificant; the estimate for the remaining three quarters is marginally significant. Comparing simply the first year (including the first quarter) with all later contract years yields a $0.84 \%$ higher quarterly growth rate in the first year (3.36\% per year), with a $t$-statistic of 2.39 .

The F-tests in Table 4 show considerable cross-industry differences in the first-quarter behavior of employment. Although a common first-

Table 4 QUARTERLY RATES OF EMPLOYMENT GROWTH BY POINT IN CONTRACT, INDUSTRY DATA*

\begin{tabular}{|c|c|c|c|c|c|c|}
\hline & $\begin{array}{l}\text { Common } \\
\text { 1st-Quart } \\
\text { Effect }\end{array}$ & $\begin{array}{c}\text { Common } \\
\text { 1st-Year } \\
\text { Effect }\end{array}$ & $\begin{array}{c}\text { Common } \\
\text { 3rd-Year } \\
\text { Effect }\end{array}$ & $\begin{array}{c}\text { F-test } \\
\text { for } \\
\text { 1st Quart }\end{array}$ & $\begin{array}{c}\text { F-test } \\
\text { for } \\
\text { 1st Year }\end{array}$ & $\begin{array}{c}\text { F-test } \\
\text { for } \\
\text { 3rd Year }\end{array}$ \\
\hline \multicolumn{7}{|l|}{ Sample E Specification } \\
\hline $\begin{array}{l}40 \text { Industries- } \\
\text { Common Seasonals }\end{array}$ & $\begin{array}{c}1.21 \\
(1.19)\end{array}$ & $\begin{array}{c}0.61 \\
(0.97)\end{array}$ & $\begin{array}{c}-0.27 \\
(-0.43)\end{array}$ & $2.91^{+}$ & 1.11 & 0.64 \\
\hline $\begin{array}{l}40 \text { Industries- } \\
\text { Industry-Specific } \\
\text { Seasonals }\end{array}$ & $\begin{array}{c}0.77 \\
(0.77)\end{array}$ & $\begin{array}{c}0.74 \\
(1.71)\end{array}$ & $\begin{array}{c}-0.23 \\
(-0.53)\end{array}$ & $2.29^{+}$ & 0.53 & 1.09 \\
\hline $\begin{array}{l}19 \text { Industries- } \\
\text { Common Seasonals }\end{array}$ & $\begin{array}{c}1.71 \\
(1.45)\end{array}$ & $\begin{array}{c}0.39 \\
(0.59)\end{array}$ & $\begin{array}{c}-0.43 \\
(-0.59)\end{array}$ & $2.65^{\dagger}$ & 1.21 & 0.86 \\
\hline $\begin{array}{l}19 \text { Industries- } \\
\text { Industry-Specific } \\
\text { Seasonals }\end{array}$ & $\begin{array}{c}1.12 \\
(1.27)\end{array}$ & $\begin{array}{c}0.59 \\
(1.12)\end{array}$ & $\begin{array}{c}-0.38 \\
(-0.73)\end{array}$ & $2.62^{+}$ & 0.36 & 1.40 \\
\hline
\end{tabular}

"The 40-industry sample has 3,936 observations; the 19-industry sample has 1,830. T-statistics are in parentheses.

${ }^{+}$F-test significant at .001 level. 
Table 5 1ST QUARTER WAGE AND EMPLOYMENT EFFECTS BY INDUSTRY*

\begin{tabular}{crrrr}
\hline Industry & \multicolumn{2}{c}{ Wage Effect } & \multicolumn{3}{c}{ Employment Effect } \\
\hline 203 & 4.70 & $(1.70)$ & -0.22 & $(-0.03)$ \\
211 & 3.51 & $(2.06)$ & -8.15 & $(-1.52)$ \\
231 & 1.79 & $(2.98)$ & -0.89 & $(-0.47)$ \\
232 & 0.71 & $(0.41)$ & 0.08 & $(0.01)$ \\
233 & 0.49 & $(0.32)$ & -5.22 & $(-1.09)$ \\
263 & 0.23 & $(0.12)$ & -3.94 & $(-0.66)$ \\
301 & -0.24 & $(-0.36)$ & 0.14 & $(0.07)$ \\
317 & 0.83 & $(0.53)$ & -6.82 & $(-1.38)$ \\
321 & 0.35 & $(0.35)$ & -1.84 & $(-0.58)$ \\
322 & 4.49 & $(1.81)$ & 3.56 & $(0.46)$ \\
324 & 3.45 & $(1.73)$ & -2.26 & $(-0.36)$ \\
333 & 0.33 & $(0.35)$ & 2.46 & $(0.84)$ \\
341 & 1.16 & $(0.98)$ & -4.64 & $(-1.25)$ \\
352 & 2.05 & $(1.01)$ & -1.11 & $(-0.17)$ \\
365 & -1.51 & $(-0.76)$ & 8.94 & $(1.44)$ \\
371 & 2.40 & $(3.07)$ & 14.71 & $(5.97)$ \\
372 & 3.02 & $(1.26)$ & 4.94 & $(0.66)$ \\
373 & 10.71 & $(3.07)$ & 0.29 & $(0.03)$ \\
374 & -1.99 & $(-0.86)$ & 11.48 & $(1.57)$ \\
\hline
\end{tabular}

${ }^{*} T$-statistics are in parentheses.

quarter effect on employment growth is statistically insignificant, industry-specific effects are very significant.

In row 1, industries are constrained to have common seasonal effects. This increases the first-quarter effect relative to that for the remainder of the first year. The data, however, strongly reject the restriction of common seasonals.

The second panel of Table 3 considers the smaller sample of 19 industries with $25 \%$ coverage. The results are consistent with the faster firstyear growth found for the 40-industry sample; but employment growth is higher in the first quarter of a contract than in the remaining three quarters of the first year. As for the 40-industry sample, an F-test clearly rejects a common zero first-quarter employment effect in favor of industry-specific nonzero effects.

Table 5 presents the industry-specific estimates of the impact of first contract periods on both wage rates and employment. The estimates correspond to the reported regressions in row 4 of Tables 4 and 5; they are for the narrower 19-industry sample and reflect industry-specific seasonals. Seven of the industries have significantly positive first-quarter effects on wages. Three industries have negative estimates; but none are 
significantly different from zero. With respect to employment, motor vehicles (SIC 371) is a significant outlier. Two other industries (SICs 365 and 374) exhibited quantitatively large increases in employment at the beginning of contracts; but these effects are only marginally statistically significant. A number of industries have negative estimated effects, but none of which are very statistically significant. There is little relation between the cross-industry patterns in wage and employment effects.

The motor vehicle industry has predictably experienced rapid employment growth at the beginning of new contracts. In fact, dropping motor vehicles from the cross-industry sample removes the significantly positive first-year effect on employment growth. Including motor vehicles in the 40 -industry sample, I reported above a $0.84 \%$ higher quarterly growth rate in employment in the first contract year than in later years, with a $t$-statistic of 2.39 . Removing motor vehicles, this five-year effect remains positive, but becomes only $.04 \%$ with a $t$-statistic of 0.12 . Section 4 examines behavior separately for the four largest auto producers as well as two large motor vehicle parts companies.

Unfortunately, many of the industries did not have sufficient concentrations of bargaining activity to provide confident estimates of industryspecific effects. The model in Section 3 yields predictions for stratifying the industries. These are empirically tested in Section 4 .

I am treating stage of contract as an instrument to examine the relation of employment to predictable wage movements. If dates of contract endings respond to an important degree to market conditions this may be inappropriate. Most contracts in the data set did end according to schedule. About $7 \%$ were reopened prior to the scheduled end. For about one-fourth of the sample there occurred a gap between one contract's scheduled end and signed agreement on a subsequent contract. Most of these delays, however, were brief periods of a month or two or less. About one-third of these gaps resulted from strikes.

Table 6 allows different behavior for wages and employment in the first year of contracts that follow unscheduled reopening. Eliminating unscheduled reopenings yields results very close to those reported in Tables 3 through 5 . The faster wage growth at the front of contracts is even more pronounced after a contract is reopened early. So eliminating these periods reduces the front loading in the remaining contracts slightly (the first quarter effect goes from $1.38 \%$ to $1.29 \%$ ). Eliminating the periods following reopenings does not affect the finding of about $3 \%$ faster employment growth in the first year of contracts. This faster firstyear growth is slightly more skewed to the first quarter of the first year in Table 6 than in Table 4; but that change is slight and statistically quite insignificant. 
Table 6 WAGE AND EMPLOYMENT GROWTH BY POINT IN CONTRACT, INDUSTRY DATA, SEPARATING EFFECTS OF EARLY REOPENINGS*

\begin{tabular}{lcc}
\hline & Wage Growth & Employment Growth \\
\hline Common 1st-Quarter Effect & 1.29 & 0.85 \\
& $(4.84)$ & $(1.10)$ \\
Common 1st-Year Effect & 0.11 & 0.69 \\
& $(0.74)$ & $(1.54)$ \\
Common 3rd-Year Effect & -0.21 & -0.23 \\
& $(-1.39)$ & $(-0.53)$ \\
Common 1st-Quarter After & 1.94 & 0.19 \\
Reopener Effect & $(2.93)$ & $(0.10)$ \\
Common 1st-Year After & 0.47 & 1.17 \\
Reopener Effect & $(1.22)$ & $(1.04)$ \\
F-test for 1st Quarter & $3.55^{\dagger}$ & $2.52^{\dagger}$ \\
F-test for 1st Year & 0.81 & 0.59 \\
F-test for 3rd Year & 0.66 & 1.14 \\
N & 3936 & 3936 \\
\hline
\end{tabular}

${ }^{*}$ Results are for the 40 -industry sample. Regressions include industry-specific seasonals. $T$-statistics are in parentheses.

'Significant at .0001 level.

\subsection{CONTRACTS EFFECTS ON INDUSTRY TURNOVER}

The finding that, on average, employment growth is at least as strong when wages are rapidly growing at the beginning of a contract raises the question about whether labor supply is directly constraining employment. More exactly, the decline in real wages during a contract could cause quits to grow over the course of a contract. The low real wage late in contracts could inhibit firms' ability to replace these quits with new hires.

I additionally examined the pattern in quits, layoffs, and new hires during the life of contracts. The BLS collected monthly data from establishments on the number of quits, layoffs, and new hires for most threedigit manufacturing industries for the years 1958 to 1981. The rate of growth in employment over a three-month period approximately equals employee additions per hundred workers minus separations per hundred workers summed over the three-monthly periods. In turn, additions are classified by the BLS as new hires or recalled workers; and separation are classified as quits or layoffs. The BLS series for number of recalls did not begin until 1976 and is not available for a number of threedigit industries; therefore I restrict attention to the behavior of quits, layoffs, and new hires.

Turnover data are available for 38 of the 40 -industry sample listed in 
Table 2. (The two industries that are eliminated are SICs 317 and 321. Data begin in 1960 for SIC 331. For ten industries, SICs 202, 203, 206, 233, 236, 281, 326, 333, 341, and 387, data begin in 1972.) The employment estimates above use a panel of 3,996 observations. Availability of the turnover data reduces the number of observations to 2,849 . I reestimated the first-year employment effect for this more limited sample. The result is a $1.14 \%$ faster quarterly rate of growth in the first year of contracts, with a $t$-statistic of 2.68 . This is somewhat above the estimate of $0.84 \%$ for the broader sample.

I estimate the first-contract-year effect on quits, layoffs, and new hires in the same fashion as for employment above. That is, industry spikes in bargaining activity are weighted by the fraction of industry workers represented by contracts. The regression includes industry-specific dummies and seasonals. Each industry turnover rate is measured relative to that period's value for manufacturing as a whole.

The faster employment growth in the first year of contracts does not come from a decrease in quits; in fact quits per hundred workers are higher in the first contract year by 0.53 . (The corresponding $t$-statistic equals 1.82.) This increase in quits in the first contract year, however, is more than offset by reduced layoffs and increased new hires. The firstyear effect on layoffs per hundred workers equals -0.52 ( $t$-statistic of -1.98 ); the first-year effect on new hires equals 0.55 ( $t$-statistic of 2.94). The possibility that employment fails to decline with first-year wage increases because increased layoffs are matched by reduced quits can thus be ruled out.

\subsection{EMPLOYMENT PATTERNS FROM COMPANY RECORDS}

This section matches contracting dates for a set of companies with agreements in the Vroman contract data to those companies' annual employment figures derived from annual reports. The annual-report employment numbers were taken from annual issues of Moody's Industrial Manual.

At a majority of companies, and all diversified corporations, employment covered by a particular collective bargaining situation is only a small fraction of total employment. I restrict attention to companies for whom workers represented in the contract data constitute at least $25 \%$ of their total work force. This is based on comparing their 1975 company employment to employment covered by their collective bargaining agreements in effect in 1975. I also restricted attention to companies who signed contracts averaging at least two years in length. With shorter contracts it is difficult to isolate within contract employment behavior from employment data at an annual frequency. 
These restrictions, as well as availability in Moody's, led to the selection of the 40 companies listed in Table 7 (along with the union or unions with whom they bargain). The companies are disproportionately concentrated in the motor vehicle and parts, farm machinery, aircraft, and cement industries. Table 7 also give each company's average employment over the sample period.

I examine employment behavior at these companies as a function of point of time in their major labor contract or contracts. I examine the years 1958 to 1984 . Some observations are lost due to missing employment figures in Moody's. I eliminate other observations due to mergers that occur in a particular year. If a merger caused the company to become part of a considerable larger company, I eliminate all subsequent observations.

For each annual observation on employment I constructed the number of months elapsed since a contract settlement. The most typical case in the data is a company that bargains with a single major union and reports employment as of particular date of the year. (December 31 is the most frequent date.) In these cases the calculation is a simple subtraction. For about one-third of the observations the employment reported in Moody's is an average annual. For these cases distance into contract is measured by the average distance over all points during the year.

As with the industry numbers, I weighted the importance of contract by the fraction of company employment represented in the bargaining data. The weights are calculated similarly to the industry weights, $S$, in equation (1), with the word "company" replacing the word "industry." That is, they equal the average number of workers represented in the collective agreement over the sample period divided by the average level of company employment. These weights, $S_{c}$, are given in Table $7 .{ }^{12}$ Nine of the companies bargain with two separate unions in the Vroman contract data; one company (Whirlpool) bargains with three. I combined multiple contract dates for a single company by weighting the duration into each contract by the fraction of company employment that is on average represented by that particular union.

Regressing employment growth on the number of months into the current contracts as well as company-specific constants and calendar year dummies yields the following:

$$
\underset{\text { Growth }}{\text { Emp }}=\frac{-.157}{(-1.63)} S_{c} \text { (Months In) } \quad N=899 \text {. }
$$

12. Although I selected companies for whom contract employment equaled at least $25 \%$ of company employment as of 1975 , for the entire sample period a couple of cases average less than $25 \%$. 
Table 7 COMPANY RESULTS

\begin{tabular}{|c|c|c|c|c|}
\hline Employer & Union & $\begin{array}{l}\text { Average } \\
\text { Employment }\end{array}$ & $\begin{array}{c}\text { Contract } \\
\text { Coverage } \\
S_{\mathrm{C}}\end{array}$ & $\begin{array}{c}\text { Employment } \\
\text { Regress } \\
\text { Coef. }{ }^{*}\end{array}$ \\
\hline Armour \& Co. & Meat Cutters & 26,830 & .36 & $\begin{array}{r}-.168 \\
(-0.20)\end{array}$ \\
\hline Kroehler Mfg. Co. & Upholsterers & 5,790 & .50 & $\begin{array}{r}-.767 \\
(-1.10)\end{array}$ \\
\hline $\begin{array}{l}\text { Hudson Pulp \& Pa- } \\
\text { per }\end{array}$ & Paperworkers & 3,390 & .41 & $\begin{array}{r}.597 \\
(1.11)\end{array}$ \\
\hline Int'l Paper Co. & Paperworkers $^{+}$ & 48,570 & .30 & $\begin{array}{c}-.353 \\
(-0.48)\end{array}$ \\
\hline New York Times & Newspaper Guild & 6,240 & .39 & $\begin{array}{c}.494 \\
(0.81)\end{array}$ \\
\hline Ideal Basic Cement & Cement Workers & 3,830 & .41 & $\begin{array}{r}-.121 \\
(-0.18)\end{array}$ \\
\hline Penn-Dixie Cement & Cement Workers & 2,940 & .68 & $\begin{array}{l}-.450 \\
(-0.62)\end{array}$ \\
\hline Marquette Cement & Cement Workers & 2,530 & .58 & $\begin{array}{l}-1.599 \\
(-1.65)\end{array}$ \\
\hline $\begin{array}{l}\text { General Portland Ce- } \\
\text { ment }\end{array}$ & Cement Workers & 2,450 & .48 & $\begin{array}{c}-.543 \\
(-0.80)\end{array}$ \\
\hline Anchor Hocking & $\begin{array}{l}\text { Glass Bottle Blowers; } \\
\text { Flint Glass Workers }\end{array}$ & 14,380 & .59 & $\begin{array}{c}.274 \\
(0.56)\end{array}$ \\
\hline $\begin{array}{l}\text { Brockway Glass } \\
\text { Mfg. }\end{array}$ & Glass Bottle Blowers & 7,610 & .55 & $\begin{array}{r}-.620 \\
(-1.39)\end{array}$ \\
\hline U.S. Steel & Steelworkers & 182,110 & .53 & $\begin{array}{r}-.558 \\
(-0.93)\end{array}$ \\
\hline ALCOA & $\begin{array}{l}\text { Steelworkers; Alumi- } \\
\text { num Workers }\end{array}$ & 46,260 & .46 & $\begin{array}{c}-.272 \\
(-0.37)\end{array}$ \\
\hline Kaiser Aluminum & Steelworkers & 23,700 & .39 & $\begin{array}{l}.153 \\
(0.22)\end{array}$ \\
\hline Reynolds Metal Co. & $\begin{array}{l}\text { Steelworkers; Alumi- } \\
\text { num Workers }\end{array}$ & 31,870 & .46 & $\begin{array}{l}-.096 \\
(-0.16)\end{array}$ \\
\hline Mirro Corp. & Steelworkers & 2,970 & .57 & $\begin{array}{l}.024 \\
(0.06)\end{array}$ \\
\hline Hughes Tool Co. & Steelworkers & 11,060 & .21 & $\begin{array}{l}-1.936 \\
(-1.19)\end{array}$ \\
\hline Timken Co. & Steelworkers & 20,350 & .47 & $\begin{array}{r}-.488 \\
(-1.06)\end{array}$ \\
\hline National Lock & Autoworkers & 5,210 & .34 & $\begin{array}{l}-1.472 \\
(-1.80)\end{array}$ \\
\hline Allis-Chalmers & Autoworkers & 29,370 & .26 & $\begin{array}{r}-.130 \\
(-0.15)\end{array}$ \\
\hline Caterpiller Tractor & $\begin{array}{l}\text { Autoworkers; Ma- } \\
\text { chinists }\end{array}$ & 60,900 & .52 & $\begin{array}{r}-.798 \\
(-1.69)\end{array}$ \\
\hline
\end{tabular}


Table 7 COMPANY RESULTS (CONTINUED)

\begin{tabular}{|c|c|c|c|c|}
\hline Employer & Union & $\begin{array}{c}\text { Average } \\
\text { Employment }\end{array}$ & $\begin{array}{c}\text { Contract } \\
\text { Coverage } \\
S_{C}\end{array}$ & $\begin{array}{l}\text { Employment } \\
\text { Regress } \\
\text { Coef. }\end{array}$ \\
\hline Int'l Harvester & Autoworkers & 63,840 & .59 & $\begin{array}{l}.373 \\
(1.06)\end{array}$ \\
\hline Deere \& Co. & Autoworkers & 44,570 & .49 & $\begin{array}{r}.438 \\
(1.04)\end{array}$ \\
\hline Westinghouse Elec. & Electrical Workers & 138,720 & .27 & $\begin{array}{c}-.106 \\
(-0.11)\end{array}$ \\
\hline Whirlpool Corp. & $\begin{array}{l}\text { Allied Indust Wkrs; } \\
\text { Electrical Workers; } \\
\text { Machinists }\end{array}$ & 20,710 & .41 & $\begin{array}{r}.859 \\
(1.10)\end{array}$ \\
\hline The Maytag Co. & Autoworkers & 3,940 & .59 & $\begin{array}{r}.339 \\
(0.78)\end{array}$ \\
\hline Ford Motor Co. & Autoworkers & 204,800 & .75 & $\begin{array}{r}-.160 \\
(-0.41)\end{array}$ \\
\hline $\begin{array}{l}\text { General Motors } \\
\text { Corp. }\end{array}$ & $\begin{array}{l}\text { Autoworkers; Electri- } \\
\text { cal Workers }\end{array}$ & 705,690 & .56 & $\begin{array}{l}-.456 \\
(-0.91)\end{array}$ \\
\hline Chrysler Corp. & Autoworkers & 129,130 & .66 & $\begin{array}{r}-.928 \\
(-2.57)\end{array}$ \\
\hline American Motors & Autoworkers & 26,360 & .51 & $\begin{array}{l}-.261 \\
(-0.66)\end{array}$ \\
\hline Dana Corp. & Autoworkers & 22,530 & .33 & $\begin{array}{r}-.439 \\
(-0.58)\end{array}$ \\
\hline Budd Co. & Autoworkers & 17,130 & .61 & $\begin{array}{l}-1.157 \\
(-2.45)\end{array}$ \\
\hline $\begin{array}{l}\text { Champion Spark } \\
\text { Plug }\end{array}$ & Autoworkers & 10,460 & .35 & $\begin{array}{r}-.414 \\
(-0.58)\end{array}$ \\
\hline Libbey-Owens Ford & Rubber Workers & 15,360 & .50 & $\begin{array}{r}1.444 \\
(2.64)\end{array}$ \\
\hline Boeing Co. & Machinists & 91,470 & .36 & $\begin{array}{r}-.610 \\
(-0.84)\end{array}$ \\
\hline Lockheed & Machinists $^{+}$ & 71,720 & .34 & $\begin{array}{l}-1.107 \\
(-1.37)\end{array}$ \\
\hline McDonnell Douglas & $\begin{array}{l}\text { Machinists } \\
\text { Autoworkers }\end{array}$ & 65,700 & .44 & $\begin{array}{r}-.543 \\
(-0.87)\end{array}$ \\
\hline $\begin{array}{l}\text { Newport News Ship- } \\
\text { building }\end{array}$ & Steelworkers & 18,430 & .91 & $\begin{array}{c}1.286 \\
(2.69)\end{array}$ \\
\hline $\begin{array}{l}\text { Gen'l Am. Trans- } \\
\text { port. }\end{array}$ & Steelworkers & 9,490 & .33 & $\begin{array}{r}-.707 \\
(-0.87)\end{array}$ \\
\hline Pullman Inc. & Steelworkers & 21,870 & .22 & $\begin{array}{r}-.621 \\
(-0.61)\end{array}$ \\
\hline
\end{tabular}

*Coefficient gives estimated impact of months since most recent contract on annual rate of employment growth. There are two sets of contracts between divisions of International Paper and the Paperworkers, and two sets of contracts between divisions of Lockheed and the Machinists. 
Months In equals number of months since the the most recent agreement. $S_{c}$ is as given in Table 7. (For companies matched with more than one union, the right-hand-side variable is the sum of $S_{c i}$ (Months In) $)_{i}$ across the unions, where $i$ indexes a particular union.) The results are comparable to the industry findings. Employment grows faster in the early portion of contracts. This effect is economically large, but not quite statistically significant. The coefficient implies employment growth slows by $1.88 \%$ for each additional year into the contract.

I also consider separate coefficients by company. These are reported in Table 7. An F-test against the null of all zero effects across companies has a value of 1.41, which is significant right at the 5\% level. Employment growth is particularly concentrated at the beginning of contracts for companies in the motor vehicle and cement industries. I hold off further discussion of the cross-company effects until Section 4 .

As an alternative to the regression reported in equation (3), I regressed employment growth on dummy variables for whether the employment observation is in the first year, second year, or later in a contract.

$$
\underset{\text { Growth }}{\text { Emp }}={ }_{(0.72)}^{1.47} S_{c}(1 \text { st Year }) \underset{(-1.19)}{-2.85} S_{c}(3 \mathrm{rd}+\text { Years }) \quad N=899
$$

The dummies are weighted by the coverage rates $S_{c}$; results are given relative to employment growth in the second year of contracts. (The regression, as in equation (3), includes company-specific constants and year-specific dummies.) The results parallel those for equation (3). Employment growth is $1.5 \%$ faster in the first year than second, and $2.9 \%$ faster in the second year than later years. These differentials, though large, are not statistically significant.

The company annual reports represented in Moody's typically do not provide wage rates, so there are no comparable regressions for wage growth for the company data. I did, however, repeat the regressions reported in Table 1, restricting the sample to the 50 bargaining matches represented by the 40 companies in Table 7 . For this subsample, which includes 432 contracts, average wage growth equaled $1.29 \%$ in the first year of contracts compared to $-0.28 \%$ in later years. The differential, $1.57 \%$, has a standard error of 0.180 . This differential is only slightly less than the differential estimated for the full sample in Table 1.

I conclude that the company results support the industry findings: as wages predictably decline during contracts, employment remains stable or actually declines. 


\section{Quasi-fixed Labor and the Structure of Labor Contracts}

A number of dynamic features of labor markets have been successfully predicted by the model of labor as a quasi-fixed factor pioneered by $\mathrm{Oi}$ (1962).${ }^{13}$ Here I derive the implications of dynamic labor demand due to costs of adjusting employment for the structure of union contracts. I focus particularly on the patterns that are predicted for wages and employment within contracts.

I consider a monopoly union setting wages for a firm or group of firms. The optimal one- and two-period union contracts are derived and compared. Dynamic labor demand provides an important rationale for longterm (two-period) bargains. With labor quasi-fixed, firms' labor demands depend negatively on anticipated future wage rates. By offering firms a long-term agreement, the union can successfully precommit to lower wages in the later stages of a contract. Such agreements will have lower wages on average than a series of shorter contracts. The declining wage rates in these long-term contracts can raise welfare for both the union and the firms because they partially overcome the time-consistency problem of the union committing to lower future wage rates.

The model clearly predicts declining wage rates over the life of a contract. The model's predictions for employment behavior depend on the bargaining setting. If the union bargains with a large number of firms as a group (as in apparel, steel, and a number of other industries) then no firm has incentive to attempt to influence subsequent bargains by laying off workers toward the end of a current agreement. The decline in wages over a contract, therefore, lead directly to an increase in employment corresponding to movement down the labor demand schedule. If a union bargains independently with individual firms, or a firm is a very large part of an industry bargaining pattern, then a firm will have incentive to reduce employment over a contract in order to achieve a lower wage in the subsequent agreement. This systematic decrease in labor demand acts to offset the impact of declining wage rates. For the linear-quadratic framework considered below, the impact of the decline in wages unambiguously dominates. Employment systematically increases over the contract, although the rate of increase is quite small.

\subsection{INDUSTRYWIDE BARGAINING WITH MANY FIRMS}

Consider first a monopoly union bargaining jointly with a large number of firms. The union sets a wage unilaterally for the industry; firms then

13. These include cyclical patterns in occupational employment and earnings differentials, the timing of employment changes for skilled versus unskilled workers, and the relative volatility of hours versus employment for various workers. 
unilaterally choose employment. Later I examine bargaining with individual firms, where firms have incentive to reduce employment to lower future wage settlements.

The monopoly-union model assumption of no bargaining over the wage rate is clearly unrealistic. A more realistic setting might be to have bargaining (e.g., Nash) over the wage rate, with both parties knowledgeable that employment will then be dictated by the firm during the life of the agreement. This set of assumptions corresponds to the "Right-toManage" contracting models discussed in Oswald (1985). What I believe to be crucial in what follows, however, is that the union face a trade-off between bargained wages and contract employment. This would hold true in Right-to-Manage models.

I represent quasi fixity by quadratic costs of adjustment as in Sargent (1978) and many other applications. Profits in period $t$ are given by:

Profit $_{t}=\left(a_{t}-W_{t}\right) L_{t}-(b / 2) L_{t}^{2}-(v / 2)\left(L_{t}-L_{t-1}\right)^{2}$.

Assuming firms maximize discounted long-run profits, the demand for labor in $t$ is described by the difference equation:

$L_{t}=\delta_{1} L_{t-1}+\left(\delta_{1} / v\right) E_{t} \sum_{i=1}^{\infty} \delta_{2}^{i}\left(a_{t}-W_{t}\right)$.

$E_{t}$ denotes the expectations operator conditional on time $t$ information. The forward root $\delta_{2}$ is smaller than the backward root $\delta_{1}$, equaling $\delta_{1} /$ $(1+d)$ where $d$ is the rate of time discount. The root $\delta_{1}$ is between zero and one, and increases with the value of $v$ relative to $b$, equaling:

$\delta_{1}=\frac{2 v}{(b+v+D v)+\left[(b+v+D v)^{2}-4 D v^{2}\right]^{1 / 2}}$

where $D$ equals $1 /(1+d)$.

If the union views the opportunity cost of labor as a constant $c$, union welfare in time period $t$ is simply $\left(W_{t}-c\right) L_{t}$. I assume the union maximizes discounted welfare over an infinite horizon (with the same discount rate as firms).

$\underset{W}{\operatorname{Max}} E_{t} \sum_{i=0}^{\infty} D^{i}\left(W_{t+i}-c\right) L_{t+i}$. 
The union maximizes subject to the constraint that employment, $L$, will be chosen by the firm according to its labor demand equation (6). In setting its wage the monopoly union takes into account the negative impact of its wage on both $L_{t}$ and labor demands in future periods.

With one period contracts the optimal wage markup set by the union has a steady-state value of: ${ }^{14}$

$$
W=\frac{2}{\left(2-\delta_{1}\right)} \frac{(a-c)}{2}
$$

Steady-state employment with one period contracts equals:

$$
L=\frac{\left(\delta_{1} / v\right)(a-c)}{\left(2-\delta_{1}\right)\left(1-\delta_{2}\right)}
$$

In setting the wage each period the union considers the negative impact today's wage has on future employment demands through the backward root $\delta_{1}$. It does not, however, take into account the negative impact the anticipation of today's wage had on earlier employment demands because these effects have passed. In a certain environment (deterministic $a_{t}$ ), the union's optimal strategy is to precommit to a path of wages arbitrarily far into the future. Under perfect precommitment the wage is lower, but this is more than offset by increased employment demand. The optimal (precommited) wage markup and employment levels have steady state values:

$$
\begin{aligned}
& W^{*}-c=\frac{a-c}{2} \\
& L^{*}=\frac{a-c}{\left(1-\delta_{1}\right)\left(1-\delta_{2}\right)} .
\end{aligned}
$$

This wage is precisely what the union would choose at a point in time if it could pretend that labor demand was not dynamic $\left(\delta_{1}\right.$ and $\delta_{2}$ equal to zero).

Union welfare under perfect precommitment compared to singleperiod wage setting equals:

14. Wage-employment dynamics with cost of adjustment and with one-period contracts are considered by Card (1986). 


$$
\frac{\left(W^{*}-c\right) L^{*}}{(W-c) L}=\frac{\left(2-\delta_{1}\right)^{2}}{4\left(1-\delta_{1}\right)}
$$

For $\delta_{1}$ equal to .25 this ratio equals $49 / 48$; for $\delta_{1}$ equal to .5 it equals $9 / 8$. Firm profits are also unambiguously greater because the wage is strictly lower.

In the absence of uncertainty these comparisons imply the optimal contract length would be infinite. More realistically, however, an infinite length contract would be undesirable because of imperfect indexing to uncertain events. Entertaining such uncertainties, an optimal length would equate the marginal benefit through precommitment to the marginal loss due to imperfect indexing. Consistent with a considerable literature on contract length (e.g., Gray, 1978), this predicts shorter contracts in the presence of greater uncertainty. It does not, however, require any assumed direct costs to contracting in order to generate noncontinuous contracting. This setting yields an additional prediction that contracts will be longer in industries with considerable fixed labor costs.

I do not pursue the issue of contract length further. I focus on the structure of wage contracts conditional on being of one or two periods in length. ${ }^{15}$ I also abstract from any uncertainty, instead assuming a constant revenue parameter $a$. Except for the issue of optimal contract length, I do not perceive any interesting interactions between uncertainty and the analysis here of predictable movements during contracts in wages and employment. ${ }^{16}$

15. I do not pursue the issue of contract length here partly because of limitations of space and focus, partly because I do not believe this model can explain the more puzzling features of contract length and indexation in the United States (see Bils 1989b); in particular, I refer to the facts that contracts are longer in industries with predictably more variable employment (e.g., durable goods industries) and contracts have been longer in periods with measurably greater real and nominal uncertainty. The model is also incapable of addressing the failure of many contracts to index. It does, of course, explain the apparent failure of contract wages to keep pace with predictable inflation.

16. Readers have suggested that uncertainty about the subsequent wage settlement might reduce labor demand near the end of contracts; that is, firms avoid hiring workers for whom the wage may soon change unpredictably. Note that such a result requires uncertainty in the contracting process itself, and is largely separate from the issue of whether labor demand and labor supply schedules are stochastic.

Given such uncertainty, it also clearly requires a dynamic labor demand function. Convex costs of adjusting labor, as I am assuming, would not yield such declines in labor demand at the end of contracts. Results from the literature on investment under uncertainty with convex costs of adjustment (e.g., Hartman 1972, Abel 1983) are that increased uncertainty about future output or input prices lead to greater investment. It is possible, however, that with concave costs of adjustment firms might delay new hires near the end of one contract to resolve uncertainty about the following contract wage. Bernanke (1983) considers capital investment under uncertainty in the presence of concave costs of adjustment. 
To continue, suppose as an alternative that the union offers firms twoperiod contracts. Bargaining occurs every other time period, say in odd time periods. If time period $t$ is an odd period then in time period $t$ the union sets both $W_{t}$ and $W_{t+1}$. In setting $W_{t}$ the union takes into account its effect on labor demand in period $t$ as well as in future periods because of the dynamics of labor demand. In setting $W_{t+1}$ the union takes these effects into account, plus the impact of $W_{t+1}$ on labor demand in period $t$. Thus, long-term contracts allow the union to partially overcome the time-consistency problem for period $t$ and other odd periods by precommiting to the next period's wage.

There is an issue as to whether these two-period contracts are time consistent. I want to allow for the possibility that if both sides wish to reopen bargaining when period $t+1$ arrives this is entirely possible. As I will show in a moment, however, firms will not want this because the wage is lower in second periods of contracts. I do want to rule out the possibility that the union can unilaterally renege on its wage contract by striking when period $t+1$ arrives. This restriction is compelling for at least two reasons. First, such a walkout would allow firms to permanently replace existing workers (NLRB v. Mackay Radio \& Telegraph Co., 1938). Second, the union could credibly commit to not walk out by writing a no-strike contract. Such a clause would allow firms to obtain back-to-work injunctions in the event of a strike (Norris-LaGuardia Act, 1932, upheld in Boys Market, Inc. v. Retail Clerks, 1970). Empirically strikes almost always occur at the end of contracts, not over the issue of reopening contracts.

I present steady-state results here, relegating derivations to the appendix. I also restrict attention to the case of the discount rate arbitrarily close to zero ( $d$ equal to zero). This implies the forward and backward roots in equation (6) are equal; and their value given in equation (7) simplifies.

Union maximization in equation (8), subject to employment demand as described in equation (6), implies the union set wage markups in first and second periods of contracts, respectively, at:

$$
\begin{aligned}
& W_{1}-c=\frac{\left(2-\delta-\delta^{2}\right)}{(1-\delta)\left(2-\delta^{2}\right)} \frac{(a-c)}{2} \text { and: } \\
& W_{2}-c=\frac{2\left(1-\delta-\delta^{2}\right)}{(1-\delta)\left(2-\delta^{2}\right)} \frac{(a-c)}{2}
\end{aligned}
$$

where $\delta$ is the commonroot in equation (7) with $D$ equal to one. The ratio of the union markup in second periods to first periods is: 
$\frac{W_{2}-c}{W_{1}-c}=\frac{2\left(1-\delta-\delta^{2}\right)}{2-\delta+\delta^{3}}$.

For instance, for $\delta$ equal to .25 this ratio equals .78 ; for $\delta$ equal to .5 it equals .31. Moderate values for $\delta$ are capable of generating very marked front-loading of contracts; therefore, it is a promising explanation for the pattern of compensation displayed in Tables 1 and 3 . For values of $\delta$ greater than about 0.62 the wage markup is actually negative in second periods. Although in theory the parameter $\delta$ can range between zero and one, for production workers empirical estimates fall in a much narrower range in the neighborhood of 0.25 (e.g., Shapiro, 1984, Bils, 1987) if time periods are interpreted as approximately annual. Relative second- and first-period wage rates for varying values of $\delta$ are presented in column $\mathrm{A}$ of Table 8.

Even in the absence of disturbances, employment varies over the contract in response to the pattern in wage rates. $L_{2}$ relative to $L_{1}$ equals:

$\frac{L_{2}}{L_{1}}=\frac{2(1+\delta)}{2+\delta}$

For $\delta$ equal to .25 this ratio equals 1.11 ; for $\delta$ equal to .5 it equals 1.2. The predictable movements in employment over the contract are less pronounced than that observed in wages because of firms' desire to smooth

Table 8 WAGE AND EMPLOYMENT PATTERNS PREDICTED BY QUASIFIXED LABOR MODEL

\begin{tabular}{lccccc}
\hline & \multicolumn{2}{c}{ Many Firms } & & \multicolumn{2}{c}{ One Firm } \\
\cline { 2 - 3 } & \multicolumn{1}{c}{$\mathrm{A}$} & $\frac{\mathrm{B}}{W_{2}-\mathrm{C}}$ & & $\frac{\mathrm{C}}{L_{2}}$ & $\frac{\mathrm{D}}{L_{1}}$ \\
\cline { 5 - 6 } & $W_{1}-\mathrm{C}$ & & $\frac{W_{2}-\mathrm{C}}{W_{1}-\mathrm{C}}$ & $\frac{L_{2}}{L_{1}}$ \\
\hline 0 & 1 & 1 & 1 & 1 \\
.1 & .936 & 1.048 & .913 & 1.024 \\
.25 & .779 & 1.111 & .735 & 1.054 \\
.5 & .308 & 1.2 & .342 & 1.091 \\
.75 & -.374 & 1.273 & -.012 & 1.117 \\
.9 & -.849 & 1.310 & -.488 & 1.166 \\
.9999 & -1 & 1.333 & -.545 & 1.174 \\
\hline
\end{tabular}


employment. Values of $L_{2}$ relative to $L_{1}$ are given for varying values of $\delta$ in column B of Table 8.

The union obtains a disproportionate share of its payoff in the first period of contracts. The ratio between periods equals:

$\frac{\left(W_{2}-c\right) L_{2}}{\left(W_{1}-c\right) L_{1}}=\frac{4(1+\delta)\left(1-\delta-\delta^{2}\right)}{(2+\delta)\left(2-\delta-\delta^{3}\right)}$

For $\delta$ equal to .5 , union welfare in second periods is only $37 \%$ of its value in first periods of contracts. Firms earn a disproportionate share of profits in later periods of contracts when wage rates are relatively low.

It is possible for two-period contracts to strictly raise payouts to both firms and the union compared to one-period contracts because they partially solve the union's time-consistency problem. Average wage markups are strictly lower under two period contracts. (For $\delta$ equal to .25 , the average wage markup is $5.4 \%$ lower with two-period contracts; for $\delta$ equal to .5 it is $8.9 \%$ lower.) Thus, it is clear that the firm can be better off.

Steady-state union welfare under two-period contracts relative to oneperiod contracts is given by:

$$
\frac{\left(W_{1}-c\right) L_{1}+\left(W_{2}-c\right) L_{2}}{2(W-c) L}=\frac{(2-\delta)^{2}\left(8-9 \delta^{2}-2 \delta^{3}+\delta^{4}\right)}{8\left(2-\delta^{2}\right)^{2}(1-\delta)}
$$

For $\delta$ equal to .25 steady-state union welfare is $0.8 \%$ higher with twocompared to one-period contracts; for $\delta$ equal to .5 it is $2.2 \%$ higher. For $\delta$ greater than about .622 , union payouts are actually lower under twoperiod contracts. This result initially appears perverse because the union has the option of setting the wage rate at the one-period contract wage for both contract periods. This latter strategy, however, is not time consistent. Anticipating a constant-wage path beyond the next two periods, the union makes a greater payoff by setting uneven wages over this period and next. Similarly, anticipating a future uneven pattern in wages as described in equations (14A) and (14B), the union does better setting uneven wages during this contract. If, however, the union could write arbitrarily long contracts this problem would go away. As discussed above, values greater than .622 for $\delta$ are probably empirically irrelevant for production labor.

\subsection{CONTRACTING WITH A SIGNIFICANT FIRM}

Wages chosen by the union depend positively on prior employment because past employment increases firms' future employment demands through the adjustment costs. (See equations (A6) and (A7) of the Ap- 
pendix.) If any single firm employs a significant fraction of the union, or if the union writes separate wage contracts for individual firms, then dynamic monopsony arises. The firm has incentive to reduce employment today to receive a lower future wage settlement. This incentive is potentially very strong (for example, in the linear-quadratic setting with one-period contracts, if the parameter $v$ equals the parameter $b$ implying a value for $\delta$ of .38, this effect reduces steady-state employment by $40 \%$ ).

The Appendix treats the case of two-period contracts written by the union for a single firm. The impact of dynamic monopsony is to reduce the forward-looking parameter (the parameter analogous to $\delta_{2}$ in equation (6)) in the second period of contracts. Anticipated future employment levels have a negative impact on employment demand in the last contract period because additional demand will raise the wages paid for that future employment. (This is in addition to the positive impact of future employment on today's demand from the adjustment costs.) This implies the labor demand schedule should systematically decline during a contract.

Although I do not obtain closed-form solutions, it is possible to calculate approximate values for wages and employment in the first and second periods of contracts for given levels of adjustment costs. Columns $C$ and D of Table 8 present wages and employment in secondcontract periods relative to first periods for varying values of $\delta . \delta$ is as given by equation (7) for no monopsony impact and for $\mathrm{D}$ equal to one. $\delta$ simply provides a convenient measure of adjustment costs; with dynamic monopsony it no longer equals the coefficient of today's employment demand on last period's employment.

Comparing Columns A and C of Table 8, at low to intermediate values of $\delta$ the union sets even steeper wage declines during contracts with dynamic monopsony. This is intuitive. Because the firm's labor-demand schedule is predictably decreasing in second periods, the union has further incentive to reduce wages in second periods. At higher values of $\delta$, however, the reverse is true. Wages decline much less during contracts, despite labor demand declining. The reason for this is as follows. With dynamic monopsony, for given-size costs of adjustment (and so for given $\delta$ ), labor demand is less dynamic. Employment demand is less positively related to future employment because the desire not to raise future wages is proportional to future employment levels. Because labor demand is less dynamic, the union has less incentive to tilt its wage schedule during contracts. At high levels of adjustment costs this dominates the direct effect on wage profiles from labor demand shifting.

Column D presents the contracting pattern in employment. As expected, for a given steepness in the wage profiles, employment is less 
inclined to rise over the contract. The shifting of labor demand offsets the movement responding to wage declines; but this offsetting is only partial. It remains true that employment predictably increases during the contract. Thus, this model is less than consistent with the findings of Section 2 of declining or stable employment during contracts.

In the next section I examine whether, nevertheless, this bargaining story can help explain cross-industry and cross-country behavior in wages and employment during contracts.

\section{Examining Cross-Sectional Patterns}

Sections 1 and 2 described how wage rates predictably decline during the course of contracts. Employment behavior was shown to be mixed across industries; but the movements are more pronounced in those industries displaying declining employment during contracts. This section examines whether patterns in wage setting and employment across the 40 three-digit industry sample and 40-company sample discussed in Section 2 agree with predictions of the model with dynamic labor demand in Section 3. The results are not supportive.

\subsection{RESULTS FROM INDUSTRY SAMPLE}

The model in the prior section explains declining wages during contracts by union efforts to commit to low future wage rates because labor demand is dynamic. Thus, the sawtooth pattern in wage rates should be stronger in industries with greater firm-specific human capital.

No definitive measure exists for these firm specific investments. I relate the front-loading of wage contracts to two proxies for labor fixity. One is the three-digit industry's labor turnover rate. This is measured by the sum of separations and accessions per hundred workers per month averaged over a three-year period. The assumption is that greater fixed labor costs reduce turnover. The other measure is the natural log of the average hourly wage rate in the industry for the year 1977 . This assumes that fixed costs rise as a fraction of labor cost at higher wage levels (Oi 1962). I measure the front-loading of wages by the differential between wage growth in the first year of contracts and in all subsequent contract years. (Wage growth is expressed at an annual rate.) These differentials were estimated in a manner analogous to the effects displayed in Table 3.

Regressing industry first-year wage effects on turnover rates for the 40 industry sample listed in Table 2 yields:

$\begin{aligned} & \text { 1st Year } \\ & \text { Wage Effect }\end{aligned}=\underset{(0.40)}{.0984}$ Turnover Rate $\quad R^{2}=.004 \quad N=40$ 
(The regression includes an intercept as well. The number in parentheses is a $t$-statistic.) The model in Section 3 predicts a significantly negative coefficient. Contrary to that prediction, there is a small positive relation between industry turnover rates and the front-loading of contracts. (The standard deviation across the 40 industries for turnover rate is 4.91; this has an estimated impact on front-loading of less than onehalf of $1 \%$.)

A possible explanation for positive coefficient in equation (19) is that workers in industries with high turnover discount future periods more heavily because they may be gone from the firm. In bargaining, such workers may prefer to front-load compensation in order to gain at the expense of new hires later in the contract. I discuss this possibility at greater length in the concluding section. I note here, however, that although the estimate in equation (19) is positive, it is close to zero. So it is not strong support for this view either.

Using the relative hourly wage as a proxy for labor fixity yields:

$\begin{aligned} & \text { 1st Year } \\ & \text { Wage Effect }\end{aligned}=\frac{-1.472}{(-0.35)} \operatorname{Ln}($ Wage $) \quad R^{2}=.003 \quad N=40$.

The estimated relation is again opposite that anticipated. This effect is quantitatively small.

As discussed briefly above, quasi-fixed labor also provides a rationale for writing longer contracts. I additionally examined the relation between average industry contract length and these same industry turnover and wage measures. Average contract length for the 40-industry sample is calculated from the Vroman data set. I found no relation between industry turnover rates and the length of industry contracts. I found only a slight positive relation between industry wages and length of contracts. (A 10\% higher industry wage is associated with $1 \%$ longer industry contracts.) Thus, the evidence on contract length does not strongly support the model of Section 3.

With respect to employment, Section 3 predicts increasing employment during contracts, but much smaller increases if firms are in a position to influence future agreements. I relate industry employment patterns to two variables designed to capture the ability of firms' to affect unionwide employment. The first is whether many agreements in the industry are between a union and multiple firms. (Apparel is an excellent example.) The second is whether pattern bargaining is prevalent in the industry. (Bargaining matches in the Vroman data set were classified by Vroman as part of pattern bargaining using a criterion established by Kochin.) I view both multiple-firm contracts and pattern bargaining as decreasing firms' 
monopsony power. I, therefore, expect employment to increase particularly during contracts under these conditions. (About 29\% of contracts in the 40 -industry sample are for more than one firm; about $51 \%$ are classified as part of a broader bargaining pattern.)

I express the industry-specific pattern in employment by the difference in the rate of employment growth in the first year of contracts from later contract years (at an annual rate). Regressing this differential on the fraction of industry contracts involving more than one firm yields:

$\begin{aligned} & \text { 1st Year } \\ & \text { Employ Effect }\end{aligned}=\begin{gathered}-5.34 \\ (-0.84)\end{gathered}$ Mult. Firms $\quad R^{2}=.018 \quad \mathrm{~N}=40$.

The sign is as expected. This states that contracts with a single firm have over 5\% faster employment growth in the first year of contracts. This effect is economically large, but statistically insignificant. I reestimated equation (21) for the smaller sample of 19 industries listed in Table 5 for whom the contracts cover at least $25 \%$ of industry employment. This dramatically reduces the coefficient to -.922 ( $t$-statistic of -0.22 ). This suggests the large, but statistically insignificant coefficient in equation (21) results from difficulty in measuring the first-year employment effect in industries with little coverage in the contract data set.

Regressing employment behavior on the fraction of industry contracts that are part of a bargaining pattern yields:

$\begin{aligned} & \text { 1st Year } \\ & \text { Employ Effect }\end{aligned}=\begin{gathered}7.38 \\ (1.17)\end{gathered}$ Pattern $\quad R^{2}=.034 \quad \mathrm{~N}=40$.

This estimate is of the opposite sign expected and is large, stating that contracts that are part of a pattern exhibit $7 \%$ faster employment growth in the first contract year. But this effect is statistically insignificant. Furthermore, using the more restrictive 19-industry sample reduces the estimated coefficient to 3.93 ( $t$-statistic of 0.70 ).

\subsection{RESULTS FROM COMPANY SAMPLE}

I examine two features of the cross-company results presented in Table 7. Is employment behavior related to the presence of an industry bargaining pattern or to a cross-industry bargaining pattern? Does employment behave differently at a dominant firm in an industry than at its smaller competitors?

I have argued that employment should particularly increase during contracts in industries displaying pattern bargaining because firms can largely take the wage settlement as given. Among the industries repre- 
sented by the 40 companies in Table 7, there are six industries with strong internal bargaining patterns. These are cement, glass bottles, pulp and paper, steel, motor vehicles, and aircraft. In addition, the pattern bargain in steel typically was applied by the Steelworkers union to subsequent contracts in aluminum; and the pattern in motor vehicles was largely applied by the United Auto Workers in subsequent agreements in motor vehicle parts and in farm machinery.

The four companies from the cement industry each exhibit declining employment during contracts. The average estimate for the four is a decline in rate of employment growth of $8 \%$ for each year into the contract. ${ }^{17}$ The two glass blowing companies display conflicting patterns, as do the two pulp and paper companies. The only company producing primarily steel is U.S. Steel. It exhibits declining employment during contracts; but U.S. Steel is so large it is unreasonable to not view it as affecting its wage settlements. All four auto companies exhibit declining employment during contracts; the average for the four companies is a decline in rate of employment growth of $5.5 \%$ for each year into the contract. All three aircraft industries display falling employment growth during contracts, the average fall for the three companies equaling $9 \%$ per year.

The industries that typically followed larger industries' settlementsaluminum, farm machinery, and motor vehicle parts-provide useful tests because it is natural to view their wage settlements as largely determined externally. The aluminum companies in the sample show little relation between employment growth and the dates of contracts. Among the four farm machinery companies, two have declining employment and two increasing employment during contracts. The three motor vehicle parts companies represented by the UAW (Budd Co., Dana Corp., and Champion Spark Plug) each display declines in employment growth during contracts; the average decline is $8 \%$ for each year into the contract. The patterns among these companies is thus at odds either with the framework of dynamic monopsony, or with the assumption that pattern bargaining lessens that monopsony power.

Larger firms should have greater monopsony power; therefore I anticipated employment declines during contracts at large firms relative to those at small firms subject to a comparable contract with the same union. Two industries are represented in Table 7 by companies of mixed sizes bargaining with a single union; these are the paper and motor vehicle industries.

17. These estimated effects must by weighted by the fraction of company employment covered by contracts, $S_{c}$, to anticipate the impact on actual company employment. 
The International Paper Company is more than ten times the size of the only other paper company in the sample, Hudson Pulp and Paper. Employment growth at International Paper on average declined by $4 \%$ for each year into a contract; employment at Hudson grew by $7 \%$ faster each additional year into contracts. Thus, this case is exactly as expected. Neither company's employment pattern, however, is statistically significant.

The motor vehicles industry provides a better case, as there are four companies represented. As already stated, all four companies exhibit declining employment during contracts. There does not appear to be any relation between size and steepness of this decline. The largest company, General Motors, exhibits the same rate of decline- $5 \%$ per year-as the group as a whole. Chrysler, the third largest producer, exhibits the sharpest declines, averaging just over $10 \%$ per year into the contract. Part of the measured employment declines during contracts at Chrysler can be attributed to employment rebounds after unscheduled contract reopenings in 1980 and 1981. As pointed out above, the much smaller vehicle parts companies display employment declines during contracts of equal or greater magnitude as the major auto companies.

Thus, relative firm size does not appear particularly promising for explaining contract patterns in employment.

\section{Conclusions}

There have been predictable patterns in wage rates and employment during labor contracts in manufacturing. Wages have grown about $1.75 \%$ faster in the first year of contracts. More puzzling, employment has also on average grown considerably faster, over 3\% faster, in the beginning year of contracts. As shown above, this pattern in employment is less uniform across industries than is the pattern in wage rates.

One possible explanation for the front-loading of wage rates is that contracters have systematically underpredicted inflation, and then repeatedly made up for it at the front of future contracts. I dismissed this explanation partly on the basis that is requires too large a systematic error in anticipating inflation over too long of a period (1958 to about $1985)$, and because the inflation rate was only 1 or $2 \%$ higher at the end of this period than at the beginning. (I also note that front-loading occurs in indexed as well as nonindexed contracts.) This explanation also fails with respect to employment: it predicts higher employment later in contracts if employment is determined largely by labor demand within a contract.

A second possible explanation for front-loading wages is that workers discount future wages at a higher rate than firms. It is sometimes argued 
that firms have greater access than individuals to financial markets. But this does not imply wages should be front-loaded. With uneven wage payments workers must invest their wages at beginning of contracts at interest rates inferior to rates available to firms. This provides additional incentive to write contracts with stable wage rates (as in the implicit contracting literature).

A more promising line of reasoning is that workers discount wages later in the contract because there is a significant probability they will soon leave the firm. Thus, front-loading is one way to tax subsequent hires in favor of the current membership. There are problems with this argument. First, more senior, less transient workers typically receive a disproportionate voice in bargaining. Second, more direct means exist for taxing new hires-two-tiered wage structures or simply wage profiles steeper than productivity with respect to seniority. Third, it predicts, counterfactually, rising employment over contracts if employment is largely determined by firms during contracts.

I have focused on quasi-fixed labor, giving rise to dynamic labor demand, as a potential explanation for the behavior of both wages and employment. Dynamic labor demand is a promising route because its predictions have been substantiated in a number of other contexts (see footnote 13). Section 3 demonstrates that small costs for adjusting employment can yield sharply falling wage rates during a labor contract. A union agrees to lower wage rates later in a contract as a means to expand employment at the front of the contract. The decline in wage rates during contracts generally predicts corresponding increases in employment. These increases are partially mitigated, however, by the costs of adjusting employment. Furthermore, if bargaining is between the union and a single firm, that firm has a strong incentive to reduce employment at later stages of a contract in order to lower subsequent wage settlements. This further offsets the prediction of increasing employment during contracts, although only partially for the linear-quadratic setting examined.

In Section 4 this explanation is put to the tougher test of explaining cross-industry and cross-company patterns in wages and employment. I conclude that it fails. Unions in industries where fixed labor costs should be higher do not write contracts with steeper declines in wage rates. Industries with strong bargaining patterns, and thus less monopsony power, do not exhibit increases in employment during contracts. ${ }^{18}$ Smaller firms in an industry with a bargaining pattern do not exhibit increases in employment during contracts.

18. This implicity treats the presence of a bargaining pattern as exogenous. This might be problematic. A union facing dynamic monopsony power as depicted in Section 3 would presumably push harder for an industry bargaining pattern. 
It may be necessary to drop the traditional interpretation that employment is predominantly chosen by the firm during the life of an agreement. As discussed in the introduction, it has become increasingly common to view wage rates as nonallocative, with firms and workers following some more vague mechanism to arrive at approximately jointly efficient employment decisions. There are two problems with this view for explaining the patterns in wages and employment. For one, it leaves the pattern for wage rates within contracts undetermined; thus the strong front-loading of wage rates is not explained. Of course, it is conceivable to wed this nonallocative view of wages with an additional motive for front-loading (e.g., higher discount rates for workers than firms). Second, this view suggests employment should not be predictably related to the stage of a contract. But employment does on average grow faster at the front of contracts (from Table 4 , by about $3.3 \%$ in the first contract year).

I would entertain a bargaining-setting intermediate between employment chosen by firms to equate marginal revenue and the wage and employment chosen efficiently to equate marginal revenue and the opportunity time of labor. It may be that employment is based more on the contract curve (efficient locus of choices) at the front of contracts, and more on the labor demand schedule as the contract progresses. At the time of contracting, assuming both parties are informed on the status of labor demand and supply, there would be no cost to specifying the level of employment as well as wage rates for the beginning of the contract. This would be beneficial, as it prevents the union markup from distorting the firm's employment decision (as noted by Leontief 1946). As the contract period proceeds, disturbances unforeseen at the time of contracting will become increasingly important. At some point it may be preferable to forgo specifying employment, instead relying on the firm to choose employment subject to the wage rate. Although the firm will reduce employment because of the union wage markup, this can be preferable because it allows employment to respond to the disturbances that occur to labor demand during the life of the contract. ${ }^{19}$

I suspect this setting can yield both declining wages and declining employment during agreements. Absent declines in wages, employment would decline during contracts as firms obtain greater latitude to set employment. Thus, wages should decline during the contract in order to induce firms to continue to choose employment near the contract curve. Ideally, wages should decline sufficiently during the contract

19. This strategy would be aided by the presence of dynamic labor demand as depicted in Section 3 . The firm will move only part way from the contract curve to its labor demand schedule because of costs of adjusting employment away from the contract curve, and then back again for the beginning of the subsequent agreement. 
to avoid any predictable decline in employment. But if it is costly to have very large variations in wages during contracts some decline in employment might yet result.

The important question is whether we observe such restrictions on firms' choices as a feature of bargaining. For the postwar period as a whole, I believe the answer is no. In the eighties there has been some emphasis on "job security" as a bargaining issue. Some provisions that have arisen with regard to employment security do apply more to the beginning of contract periods. ${ }^{20}$ For the most part, however, it again becomes necessary to appeal to unobservable behavior on the part of unions and firms.

\section{REFERENCES}

Abel, A. B. 1983. Optimal investment under uncertainty. American Economic Review 73(1):228-33.

Barro, R. J. 1977. Long-term contracting, sticky prices, and monetary policy. Journal of Monetary Economics 3(4):305-16.

Bernanke, B. S. 1983. Irreversibility, uncertainty, and cyclical investment. Quarterly Journal of Economics 98(1):85-106.

Bils, M. 1989. Testing for contracting effects on employment. NBER Working Paper 3051, July.

- 1989b. Indexation and contract length in U.S. manufacturing. Manuscript, Hoover Institution, November.

. 1987. The cyclical behavior of marginal cost and price. American Economic Review 77(5): 838-55.

Card, D. 1986. Efficient contracts with costly adjustment: Short-run employment determination for airline mechanics. American Economic Review 76 (5), 1045-71.

Caskey, J., 1985. Modeling the formation of inflation expectations: A Bayesian approach. American Economic Review 75 (4): 768-76.

Clark, J. M. 1923. Studies in Economics of Overhead Costs. Chicago: University of Chicago Press.

Fischer, S. 1977. Long-term contracts, rational expectations, and the optimal money supply rule. Journal of Political Economy 85(1):191-205.

Gray, J. A. Wage indexation: A macroeconomic approach. Journal of Monetary Economics 2:221-35. 86(1):1-18.

Haberler, G. 1937. Prosperity and depression. London: George Allen \& Unwin Ltd.

Hall, R. E. 1980. Employment fluctuations and wage rigidity. Brookings Papers on Economic Activity (1) 91-123.

1988. Arthur Okun memorial lectures: Booms and recessions in a noisy economy. Lectures presented at Yale University, October 1988.

20. For example, contracts signed in the auto industry in 1982 required a rescinding of plans to close four plants at General Motors, and at Ford and General Motors a moratoriam for just the first two years of the agreement on plant-closings due to subcontracting of work. 
Hartman, R. 1972. The effects of price and cost uncertainty on investment. Journal of Economic Theory 5(4):258-66.

Kruse, D. (1989) Profit sharing in the 1980s: Disguised wages or a fundamentally different form of compensation. Manuscript, Rutgers University, November.

Leontief, W. 1946. The pure theory of the guaranteed annual wage contract. Journal of Political Economy 56(1):76-79.

Oi, W. 1962. Labor as a Quasi-Fixed Factor. Journal of Political Economy 70:538-55.

Oswald, A. J. 1985. The economic theory of trade unions: An introductory survey. Scandanavian Journal of Economics 87:160-93.

Pigou, A. C. 1927. Industrial Fluctuations. London: Macmillan.

Sargent, T. J. 1978. Estimation of dynamic labor demand schedules under rational expectations. Journal of Political Economy 86(16):1009-44.

Shapiro, M. D. 1984. Dynamic factor demands. Doctoral thesis, MIT.

Taylor, J. B. 1979. Staggered wage setting in a macro model. American Economic Review 69(2):108-13.

Vroman, W. 1984. Wage contract settlements in U.S. manufacturing. Review of Economics and Statistics 66(51):661-65.

- 1986. Union wage settlements, incomes policies and indexation. Manuscript, Urban Institute, October.

\section{APPENDIX: Two-Period Contracts}

This appendix derives time-consistent two-period wage setting by unions, given that firms choose employment period-by-period to maximize profits. I treat bargaining between the union and a single firm. In this case employment demand is distorted by the firm's desire to reduce future wage rates. The case of bargaining with many independent firms, where firms can essentially take the wage path as given, is then treated as a simplifying special case.

Time periods (e.g., years) are denoted by the subscript $t$ as in the text. It is convenient to introduce a second-time subscript $\tau$, which lasts two periods of the unit measured by $t$ (e.g., $\tau$ is in units of two years). Twoperiod wage contracts are specified by the union in each $\tau$ period. This contract specifies first- and second-period wage rates; denote these by $W_{\tau}{ }^{A}$ and $W_{\tau}{ }^{B}$, respectively. Firms choose employment in each of the two periods; denote these choices by $L_{\tau}{ }^{A}$ and $L_{\tau}{ }^{B}$.

I solve for union wage setting and firm employment setting by method of undetermined coefficients. Assume the firm's dynamic firstorder conditions for employment in odd (A) and even (B) periods can be written in the form:

$$
\begin{aligned}
& L_{\tau}^{A}=g_{1 A} L_{\tau-1}^{B}+g_{2 A} L_{\tau+1}^{B}+k_{A}\left(a-W_{\tau}^{A}+X_{A}\right), \\
& L_{\tau}^{B}=g_{1 B} L_{\tau-1}^{A}+g_{2 B} L_{\tau+1}^{A}+k_{B}\left(a-W_{\tau}^{B}+X_{B}\right) .
\end{aligned}
$$


$a$ is the marginal revenue product parameter, as in the text. The $g^{\prime} s, k^{\prime} s$, and $x^{\prime}$ s are all constant parameters. Solutions for the firm's problem will in fact fit this form. (Actually this is overly general, as the parameter $X_{A}$ will equal zero.)

These equations can be manipulated to yield $L_{\tau}^{A}$ as a function of $L_{t-1}^{A}$ and anticipated future wage rates:

$L_{\tau}^{A}=\beta_{1} L_{\tau-1}^{A}+\frac{\beta_{1}}{g_{1 A} g_{1 B}} \sum_{i=0}^{\infty} \beta_{2}{ }^{i} \epsilon_{\tau+1}^{A}$

where:

$\epsilon_{\tau}^{A}=k_{A}\left(a-W_{\tau}^{A}+X_{A}\right)+g_{1 A} k_{B}\left(a-W_{\tau-1}^{B}+X_{B}\right)+g_{2 A} k_{B}\left(a-W_{\tau}^{B}+X_{B}\right)$.

Similarly for even $(B)$ periods:

$L_{\tau}^{B}=\beta_{1} L_{\tau-1}^{B}+\frac{\beta_{1}}{g_{1 A} g_{1 B}} \sum_{i=0}^{\infty} \beta_{2}^{i} \epsilon_{\tau+1}^{B}$

where:

$\epsilon_{\tau}^{B}=k_{B}\left(a-W_{\tau}^{B}+X_{B}\right)+g_{1 B} k_{a}\left(a-W_{\tau}^{A}+X_{A}\right)+g_{2 B} k_{A}\left(a-W_{\tau+1}^{A}+X_{B}\right)$.

The parameters $\beta_{1}$ and $\beta_{2}$ are given by:

(i) $\beta_{1}=\frac{1}{2 g_{2 A} g_{2 B}}\left\{1-\left(1-4 g_{1 A} g_{1 B} g_{2 A} g_{2 B}\right) \cdot{ }^{5}\right\}$,

(ii) $\beta_{2}=\frac{\left(g_{2 A} g_{2 B}\right) \beta_{1}}{g_{1 A} g_{1 B}}$

The union's maximization problem is as defined by equation (6) in the text. (I treat the limiting case of no discounting.) Manipulating the union's first-order conditions yields the following expressions for wage markups in odd (A) and even (B) periods:

$$
\begin{aligned}
& W_{\tau}^{A}-c=P_{\tau}^{A}\left\{L_{\tau}^{A} / k_{A}-g_{1 B} L_{\tau}^{B} / k_{B}\right\}, \\
& W_{\tau}^{B}-c=P_{\tau}^{A}\left\{\left[1-g_{2 A}\left(g_{1 B}+\beta_{1} g_{2 B}\right)\right]\left[L_{\tau}^{B} / k_{B}-g_{2 A}\left(1+g_{2 B} / g_{1 B}\right) L_{\tau}^{A} / k_{A}\right]-g_{1 A} L_{\tau+1}^{A} / k_{A}\right\} .
\end{aligned}
$$


$P_{\tau}{ }^{A}$ denotes the union's projection of these variables $\left(L_{\tau}{ }^{A}, L_{\tau}{ }^{B}\right.$, and $\left.L_{\tau+1}^{A}\right)$ on information dated prior to $t$. The most recent information is in the form of the firm's employment choice $L_{r-1}^{B}$.

To find the impact of the firm's choice of $L_{-1}^{B}$ on future wages it is necessary to define $L_{\tau}^{A}, L_{\tau}^{B}$, and $L_{\tau+1}^{A}$ solely as functions of $L_{\tau-1}^{B}$. Combining equations (A1), (A2), (A6), and (A7), $L_{\tau_{-}}^{B}$ can be written as:

$L_{\tau}^{B}=\Gamma L_{\tau-1}^{B}+\frac{\Gamma \mu}{\alpha_{1}-\alpha_{2} \Gamma}$,

where the parameters $\Gamma$ and $\mu$ are given by:

(i) $\Gamma=\frac{\alpha_{\mathrm{o}}-\left(\alpha_{\mathrm{o}}^{2}-4 \alpha_{1} \alpha_{2}\right)^{.5}}{2 \alpha_{2}}$

(ii) $\mu=\begin{gathered}2 K_{B}\left(a-c+X_{B}\right)+\left[k_{A}\left(g_{1 B}+g_{2 B}\right)+k_{B} g_{1 A}+\right. \\ \left.k_{B}\left(g_{2 A}+\beta_{2} g_{1 A}\right)\left(1-g_{2 B} g_{1 A}-\beta_{1} g_{2 B} g_{2 A}\right)\right]\left(a-c+X_{A}\right)\end{gathered}$

and $\alpha_{0}, \alpha_{1}$, and $\alpha_{2}$ are given by:
(i) $\quad \alpha_{0}=\begin{aligned} & 4-2 g_{2 B}\left(g_{1 A}+\beta_{1} g_{2 A}\right) \\ & -\alpha_{1}\left(g_{2 A}+g_{1 B} k_{A} / k_{B}\right) / g_{1 A}-g_{1 A}\left(g_{2 B}+g_{1 A} k_{B} / k_{A}\right),\end{aligned}$
(ii) $\alpha_{1}=g_{1 A}\left[g_{1 B}+\left(k_{B} / k_{A}\right)\left(g_{2 A}+\beta_{2} g_{1 A}\right)\left(1-g_{2 B} g_{1 A}-\beta_{1} g_{2 B} g_{2 A}\right)\right]$,
(iii) $\alpha_{2}=\left(g_{2 B}+g_{1 A} k_{B} / k_{A}\right)\left(g_{2 A}+g_{1 B} k_{A} / k_{B}\right)$.

Projections for $L_{\tau}^{A}$ and $L_{\tau+1}^{A}$ on $L_{\tau-1}^{B}$ that parallel equation (A8) can also be calculated. (I omit these in the interest of space.)

Using equation (A8) and the comparable equations for $L_{\tau}^{A}$ and $L_{\tau+1}^{A}$, the impact of the firm's choice for $L_{\tau-1}^{B}$ on periods $\tau^{\prime} s$ wage rates can be calculated from (A6) and (A7) as:

$$
\begin{gathered}
\frac{d W_{\tau}^{A}}{d L_{\tau-1}^{B}}=\frac{g_{1 A}+g_{2 A} \Gamma}{2 k_{A}}-\frac{g_{2 A} g^{2}{ }_{1 B} \Gamma,}{k_{B}} \\
\frac{d W_{\tau}^{B}}{d L_{\tau-1}^{B}}=\left[1-g_{2 B}\left(g_{1 A}+\beta_{1} g_{2 A}\right)\right]\left[\frac{\Gamma}{k_{B}} \frac{\left(g_{2 A}+\beta_{2} g_{1 A}\right)}{2} \frac{\left(g_{1 A}+\Gamma g_{2 A}\right.}{k_{A}}+\frac{\left.\Gamma g_{1 B}\right)}{k_{B}}\right] \\
\frac{g_{1 A}{ }^{2} \Gamma}{2 k_{A}}-\left(\frac{g_{2 A}}{k_{A}}+\frac{g_{1 B}}{k_{B}}\right) \frac{g_{1 \mathrm{~A}} \Gamma^{2} .}{2}
\end{gathered}
$$


The firm's problem is to choose employment in each period of a contract to maximize a sequence of payouts of the form in equation(5) of the text, knowing that its choice for $L_{\tau}^{B}$ influences wage rates in period $\tau+1$ through the equations (A11) and (A12) shifted forward one period.

The firm's dynamic first-order condition with respect to $L_{\tau}^{A}$ yields:

$L_{\tau}^{A}=\frac{1}{b+2 v}\left[v L_{\tau-1}^{B}+v L_{\tau}^{B}+\left(a-W_{\tau}^{A}\right)\right]$.

Comparing equations (A1) and (A13) yields:

(i) $X_{A}=0$,

(ii) $k_{A}=\frac{1}{b+2 v}$,

(iii) $g_{1 A}=g_{2 A}=g_{A}=v k_{A}$.

The parameters for the first-order condition for $L_{\tau}^{B}$ are complicated by the dynamic monopsony power; this first-order condition is:

$$
\begin{aligned}
L_{\tau}^{B}=\frac{1}{b+2 v+\Gamma \theta} & {\left[v L_{\tau}^{A}+\left(\frac{1-\Gamma}{2}+\frac{k_{A} g_{1 B} \Gamma}{k_{B}}\right) L_{\tau+1}^{A}\right.} \\
& \left.-\frac{\Gamma \theta \mu}{\alpha_{1}(1-\Gamma)}+\left(a-W_{\tau}^{B}\right)\right],
\end{aligned}
$$

where the parameter $\theta$ is shorthand for $\left(d W_{\tau}^{B} / d L_{\tau-1}^{B}\right)$ as given by equation (A12). Comparing equations (A2) and (A15) yields the following:

(i) $X_{B}=\frac{-\Gamma \theta \mu}{\alpha_{1}(1-\Gamma)}$

(ii) $k_{B}=\frac{1}{b+2 v+\Gamma \theta}$

(iii) $g_{1 B}=v k_{B}$

(iv) $g_{2 B}=\frac{g_{1 B}}{2}\left(1-\Gamma+2 g_{A} g_{1 B} \Gamma\right)$.

It is then straightforward to calculate values for steady-state wages and employment for both first (A) and second (B) periods of contracts condi- 
tional on a level of labor adjustment costs (the parameter $v$ relative to $b$ ). The four equations (A1), (A2), (A6), and (A7) yield steady-state values for $W^{A}, W^{B}, L^{A}$, and $L^{B}$ given values for the $g, k, X$, and $\beta$ parameters. In turn, these parameters can be calculated (approximately) from the set of equations (A5), (A9), (A10), (A12), (A14), and (A16). Results for varying values of adjustment costs are discussed in the text and displayed in Columns C and D of Table 8.

The text states that the dynamic monopsony power acts principally by reducing the positive relation between employment in the second periods of contracts and future employment. This is revealed by inspection of the equilibrium values for the $g$ parameters in equations (A14) and (A16). Consider the case of $\delta$ equal to .25 (row 2 of Table 8). Absent dynamic monopsony, this implies values of .235 for all four $g$ parameters. With monopsony, $g_{1 A}$ and $g_{2 A}$ remain at .235; $g_{1 B}$ approximately equals .235; but $g_{2 B}$ decreases to .115. For $\delta$ equal to $.5, g_{1 A}$ and $g_{2 A}$ are equal to $.4 ; g_{1 B}$ equals .4003 ; and $g_{2 B}$ decreases to .185 .

If bargaining is between a union and many firms, none of which is particularly large, then it is natural to view firms as taking the wage profile as given. This simplifies calculations considerably. Steady-state values for $W^{A}, W^{B}, L^{A}$, and $L^{B}$ continue to be given by equations (A1), (A2), (A6), and (A7). The $g, k, X$, and $\beta$ parameters simplify as follows:

(i) $X_{A}=X_{B}=0$,

(ii) $k_{A}=k_{B}=\frac{1}{b+2 v}$

(iii) $g_{1 A}=g_{2 A}=g_{1 B}=g_{2 B}=\frac{v}{b+2 v}$,

(iv) $\quad \beta_{1}=\beta_{2}=\delta^{2}$.

where $\delta$ is given by equation (7) in the text.

Results for bargaining with many firms are discussed in the text and presented in Columns A and B of Table 8.

\section{Comment}

GARY D. HANSEN

In this paper, two properties of observed long-term contracts are presented as stylized facts to be interpreted theoretically. A model of wage 
bargaining between a union monopolist and a firm that faces costs of adjusting employment is developed that is capable of accounting for one of these stylized facts. The model has further implications that are shown to be largely inconsistent with observed patterns of employment and wages over the length of contracts. Although the answers may not be completely satisfactory, the paper raises interesting questions concerning the relationship between employment levels and the timing of labor compensation.

My comments are divided into three parts. In Section 1, I discuss the stylized facts documented in this paper and argue that convincing evidence is presented for only one of them. In Section 2, I comment on the theoretical model used to interpret these facts. Finally, in Section 3, I discuss alternative ways one might interpret observed employment and compensation patterns over contracts. In particular, I argue that the evidence presented seems not inconsistent with employment being determined as a part of an Arrow-Debreu equilibrium where the timing of compensation simply does not matter.

\section{The Stylized Facts}

Two facts describing the behavior of wages and employment over longterm contracts are drawn from the data analysis presented in this paper: (1) on average, real wages grow $1.75 \%$ faster in the first year of contracts than in subsequent years; and (2) employment has grown on average $3 \%$ faster in the first year of contracts than in subsequent years.

These two facts are arrived at from studying data on employment, wages, and the timing of contracts for various manufacturing industries. Although the facts listed above were obtained from pooling all of these industries, results considering each industry individually are given in Table 5. This table shows that the front-loading of wages at the beginning of contracts is widespread across many of these industries. The wage effect is statistically significant for 7 out of the 19 industries and there are no significant negative coefficients. This result, that real wages are higher at the beginning of contracts, is not surprising or controversial and is usually regarded as resulting from the fact that contract wages are not indexed (or only partially indexed) to the rate of inflation. In Table 1, however, results are presented that show front-loading of wages is also a feature of indexed contracts.

The employment effect that Bils documents is much less robust. He does find that the first year employment growth effect is statistically significant when all industries are included in the sample. However, when considering each industry separately (see Table 5), the automobile 
industry is the only one for which the employment effect is statistically significant. This leads one to question whether front-loading of employment growth is a feature of manufacturing labor contracts generally or if it is only a feature of this one particular industry. In the revised version of the paper published here, results from dropping motor vehicles from the cross-industry sample are included. Bils finds that in this case, the first-year effect on employment growth is, in fact, no longer statistically significant and the coefficient is close to zero.

The hypothesis that front-loading of employment growth is a feature of only the automobile industry is also supported by the evidence from individual companies given in Table 7. In that table, only 5 out of 40 companies exhibit a statistically significant employment effect. Of these five, two display lower employment growth in the first months of a contract. The three firms which do display significantly higher employment growth in the early periods of a new contract are all part of the automobile industry, which is consistent with the industry results in Table 5. Given that the automotive industry appears to be a special case, it would be useful to study this industry more carefully to learn why employment grows faster at the beginning of contracts in this industry but not in others.

In summary, this paper provides convincing evidence for the first empirical fact listed above. There is, however, little evidence of a positive first-year effect on employment growth in manufacturing industries in general. But there is certainly no evidence in this data that employment grows faster as wages fall during the later periods of a contract, as predicted by some models, including the one studied in this paper.

\section{Interpretation}

The task of the theoretical section of the paper is to provide a model that simultaneously predicts faster growth in wages at the beginning of long-term contracts but not slower employment growth during the same period. The model is successful in predicting the front-loading of compensation but is unsuccessful in explaining observed employment patterns.

The model studied consists of a number of identical workers whose preferences are described by a constant opportunity cost of working, $c$. If the real wage is higher than $c$, these workers are willing to supply their entire time endowment as labor. The firm is assumed to face costs of adjusting employment. This implies that the firm's demand for labor will depend not only on the current wage, but all future wages as well.

Labor is assumed to be traded on a spot market each period; employ- 
ment is not predetermined by the contract. Wages are determined by a union monopolist that maximizes the present value of total payments to labor net of opportunity costs, exploiting the labor demand curve. There is a natural incentive for long-term (infinite length) contracts in this model since both the firm and the union would benefit from setting wages for all periods in advance, hence taking into account the effect of future wages on current employment. The possibility of infinite length contracts is ruled out, however, and the union is assumed to be able to precommit to wages only for some finite number of periods (two).

A result obtained from reasonable parameterizations of this model is that wages are higher in the first period of contracts relative to the second. This follows from unions recognizing that, because of the adjustment costs, lower wages in the second period imply higher employment in both periods while lower wages in the first period only affects firstperiod employment. However, the model implies, even with adjustment costs, that employment is higher in the second period when wages are lower. Thus, the model is able to account for the first stylized fact, but not the second.

In an attempt to correct this problem, Bils considers the case of dynamic monopsony, where the union negotiates with only one firm. The intuition is that this opens up an incentive for the firm to lower employment in the second period in order to be in a stronger bargaining position. It turns out, however, that employment is still higher in the second period, but the ratio of second- to first-period employment is less than in the case where there are many firms. Additional evidence against this interpretation is contained in Section 4 of Bils, where regression results are presented that do not support the hypothesis that the first-year employment effect is smaller when a union negotiates with many firms or when there is pattern bargaining.

This model represents a reasonable first shot at explaining the observed pattern of wages using a simple bargaining model. There are directions one might pursue to improve the model. In particular, an undesirable feature is that unions are assumed to possess what is perhaps an implausible amount of market power. In particular, one might expect that unemployed workers are able to impose some limits on the market power of the union by exerting downward pressure on wages. Thus, one might want to consider more complicated bargaining arrangements. Another possible improvement would be to formulate the model so that finite length contracts emerge endogenously.

I see no reason, however, to expect that these improvements would enable the model to better explain the data. This opinion is based largely on the evidence presented in Section 4 on whether industries in which 
costs of adjusting employment are important (where firm specific human capital is important) are more likely to display stronger first-year wage effects. Using two different proxies for the importance of firmspecific human capital, no evidence is found that this leads to a larger first-year wage effect. In addition, no support is found for the hypothesis that these lead to longer contract lengths. It would appear that more progress might be made by considering a different interpretation rather than improving the current one.

\section{Alternative Interpretations}

The goal of this paper is to explain observed comovements of compensation and employment over the length of labor contracts in manufacturing industries. The view of labor markets underlying the analysis is that observed patterns of compensation are important for observed patterns. That is, not just total compensation, but how that compensation is distributed over time is important for determining employment levels.

An alternative view, which underlies real business cycle models and other neoclassical macromodels, is to interpret real allocations as competitive equilibria of some general equilibrium economy. Under this interpretation, as long as there are complete markets and contracts are enforceable, only total compensation for services provided matters and the timing of compensation is irrelevant. ${ }^{1}$ Although one may suggest a sequence of markets interpretation for a given competitive equilibrium (for example, this may involve labor being paid its marginal product each period), such interpretations do not affect real allocations or welfare. Observed wage series clearly represent some state-contingent payments, but determining exactly what these payments represent is difficult. For this reason most applications of real business cycle models do not confront wage data.

I view the empirical results presented in this paper (ignoring the automotive industry) as largely consistent with an interpretation of this sort. The fact that employment is essentially unrelated to the pattern of compensation over the length of contracts can be interpreted as evidence in favor of its irrelevance.

Many may feel uncomfortable with a model that has nothing to say about the timing of compensation over time. Bils expresses this opinion in the conclusion of his paper. If one wishes, however, one can attempt to interpret what the bundle of state-contingent payments a given wage

1. This does not require that the equilibrium be Pareto optimal. There can well be externalities, taxes or other distortions. 
series represents. In the case of an Arrow-Debreu economy, one could study a particular decentralization and compare the relative prices obtained from the model with relative prices observed in reality. The decentralization chosen, however, will certainly not be unique. For example, in work by Sargent and myself on straight-line and overtime employment (Hansen and Sargent 1988), we studied a general equilibrium model in which the time-and-a-half premium for overtime work emerges from a very natural decentralization of our model. In addition, there were other reasonable interpretations in which workers do not get paid an overtime premium. Of course, equilibrium allocations and welfare are the same no matter which interpretation is assumed.

The advantage of a model like the one in the current paper is that the timing of compensation becomes determinate. It is not clear, however, that this is necessarily desirable. Once again, in the example of overtime compensation, there are industries that do not pay a wage premium for overtime. In our paper, Sargent and I argue that an alternative decentralization of the same model appears to be consistent with the compensation pattern observed in these industries. ${ }^{2}$ Consulting Table 5 of the paper, it is clear that not all industries display higher wage growth at the beginning of contracts, although it is common. This practice is not always observed even among those industries with the highest percentage of employees covered by union contracts. Thus, it may well be that observed wages in these industries are determined by precisely the same model, but just reflect different state-contingent payments.

\section{REFERENCE}

Hansen, C. D., and T. J. Sargent. 1988. Straight time and overtime in equilibrium. Journal of Monetary Economics 21(2): 281-308.

\section{Comment}

ANDREW OSWALD

In this useful research, Mark Bils makes four main points. First, he shows that, in U.S. union labor contracts, wage growth is front-loaded. In other words, there are spikes in real pay after the signing of new contracts. Second, employment growth, too, is greatest early on in these

2. In particular, this decentralization involves paying the same wage for all shifts. This wage will exceed the straight-time wage paid when overtime workers are paid a premium. Total compensation for labor services provided is, of course, the same in both interpretations. 
contracts. Third, Bils develops a model of a monopoly trade union that maximizes an intertemporal utility function against a simple dynamic labor-demand curve. This model predicts (1) falling wages within a contract, and (2) (probably) rising employment over a contract. Fourth, the model has other implications (for example, about the relationship between the wage gradient and the rate of labor turnover, and between the wage gradient and the level of wages). These are rejected by the data. Mark Bils ends by concluding that what we need is a different kind of model-possibly one with contract curve equilibria.

I shall go through these arguments in turn, but let me start by giving my broad reactions.

Point 1. I think the evidence on front-loaded pay growth is convincing. However, it is worth bearing in mind that the effect is a small one. On average the real wage falls only a percent or two through a three-year contract.

Point 2. The evidence on employment declines is much weaker. Having looked hard at these numbers I suspect the author is right; but statistically there is not nearly enough to convince a skeptic.

Point 3. Although I worked for a time on models of this kind, I believe that the monopoly union framework is not the best way to think about trade union wage formation. This type of model says the reason union $x$ has wage $y$ is because the union is so concerned about marginal job losses that it does not want higher pay. I now believe this to be fundamentally wrong. In my view the typical union $x$ has wage $y$ because it lacks the bargaining power to do better.

Point 4. It is not easy to know the right interpretation of Bils's findings, but the following points occurred to me. One is that the author finds a saw tooth in real wages, and this is the familiar pattern generated in the nonunion world of nominal contracts. If there are good reasons for it there, it should not be surprising that those reasons could be at work also in the union sector where there is some indexing. Next, why does pay (or its growth) fall through a contract? If, as explored below, workers have higher discount rates than firms, declining pay may be optimal. Say this were the correct explanation for the paper's findings. Two kinds of phenomena could then be observed at the end of contracts. First, because its relative remuneration is low, the firm might find it comparatively difficult to hire, and have a higher quit ratio. Second, the firm might prefer to delay its hiring decisions for the last few months of an expiring contract in order to discover the next rate of pay it will be required to offer. This would explain the observed intracontract employment declines. 
Turning to details, consider Table 3, and look at the left-hand column. This is compelling evidence: wages jump at the start of a new contract and decline thereafter. This is true even of indexed contracts. Now consider Table 4 on employment growth; again look at the left-hand column. This result is very much weaker statistically.

As Table 5 shows, in fact, the wage effect is positive almost always, and sometimes individually significantly different from zero (too tough a test, thinking about the appropriate null here). For employment, by contrast, ten coefficients are negative and nine are positive. The Bils result is being driven-an appropriate word-by SIC 371, the motor vehicle industry.

On more theoretical issues, Bils's model assumes that a union chooses to pay to maximize discounted labor income subject to an $A R(1)$ demand function. Why would a real union want to maximize merely discounted income? We know most unions (1) do not make the necessary internal cash transfers among members and (2) have layoffs-by-seniority whereby the majority of seniors have a negligible chance of losing their jobs. Why assume labor demand is $A R(1)$ when the evidence is typically for $A R(2)$ ? Why assume a union can set pay when it typically has to bargain over it? As it turns out, however, Bils himself concludes against the model.

The monthly quit rate in U.S. manufacturing firms of over $1000 \mathrm{em}-$ ployees is about $1.5 \%$, which is annual turnover of about a fifth of employees per year. Think of the preferences of workers at the start of a three-year contract. A sizable proportion know they will leave, so would like to weight compensation forward rather than backward. I would not expect a big wage gradient, if only because seniors are likely to have a disproportionate influence, but this is a plausible way to predict a little front-loading of pay. If workers have relatively poor access to capital markets, that reinforces the argument.

My theoretical interpretation has other implications. Wage frontloading should be similar across sectors (because preferences, not technology, are my explanation for the wage gradient); front-loading should be greater where pay is low, assuming that capital market imperfections bite most there; front-loading should be greater where turnover is high, for that is where discounting is effectively greatest. Bils's cross-section results are modestly consistent with these predictions.

Miscellaneous points are as follows. (1) There is now evidence from Leonard and Blanchflower, Millward, and Oswald (1989) that strong unions depress employment growth. Strong unions may also be the ones with long contracts. (2) The regressions are hard to interpret because entering essentially only time on the right-hand side produces a description rather than a model. I would be pleased to see more concen- 
tration on identification issues and direct wage-employment correlations. (3) There is scope for confusion here between levels and growth rates, and I think more explanation, particularly of the size of estimated effects, would be helpful. (4) Maximum profit functions are convex in wages, so those with a taste for such models might use this route to predict wage variation. (5) Intuitively I wonder about the robustness of the falling wage prediction. A low wage today boosts demand tomorrow, and it seems likely that in some formulations this might dominate. (6) The closing remarks-on this work as establishing the need for a model without a labor demand curve-are too ambitious.

\section{REFERENCES}

Blanchflower, D. G., N. Millward, and A. J. Oswald. 1989. Unionization and employment behavior. NBER Working Paper No. 3180, November.

Leonard, J. S. 1985. Employment Variation and Wage Rigidity: A Comparison of Union and Non-Union Plants, University of California, Berkeley.

\section{Discussion}

Matthew Shapiro suggested that labor demand may shift with the resolution of uncertainty in contracting. He also suggested that measurement error in the employment numbers may explain some of the findings. Laurence Ball replied that Bils placed less emphasis on the employment facts than the wage facts.

Robert Gordon suggested that changing the sample of the data might shed light on the employment findings. Ben Bernanke noted that for 13 industries the effects on wages and employment are in opposite directions.

Olivier Blanchard suggested looking within the manufacturing sector at flows into and out of employment and particularly at the components of accessions and separations. Christopher Ragan noted that frontloaded contracts are not very new and wondered whether their presence was due to strategic reasons or just incomplete indexation. Ball responded that there was no natural reason for incomplete indexation when wages can be set separately for different years.

William Brainard noted that some contracts are settled after strikes so the rate of discount may differ between the firm and the workers. Stanley Fischer noted that the workers may have different preferences from their negotiators, providing another reason why the discount rates may differ. Ball responded that different discounts rates across people was not that appealing an explanation. 
